\title{
DESIGN, CONSTRUCTION, AND OPERATION OF A LIFE-CYCLE TEST SYSTEM FOR THE EVALUATION OF FLUE GAS CLEANUP PROCESSES
}

By

H. W. Penniline

J. T. Yeh

J. S. Hoffman

E. J. Longton

P. A. Vore

K. P. Resnlk

F. N. Gromlcko

December 1995

For

U.S. Department of Energy

Pittsburgh Energy Technology Center P.O. Box 10940

Plttsburgh, PA 15236

By

Pittsburgh Energy Technology Center

P.O. Box 10940

Pittsburgh, PA 15236

and

Gilbert/Commonwealth Incorporated

P.O. Box 618

Library, PA 15129 


\section{DISCLAIMER}

This report was prepared as an account of work sponsored by an agency of the United States Government. Nelther the United States Government nor any agency thereof, nor any of their employees, make any warranty, express or implied, or assumes any legal liabllity or responsibility for the accuracy, completeness, or usefulness of any information, apparatus, product, or process disclosed, or represents that th use would not infringe privately owned rights. Reference herein to any specinic commercial product, process, or service by trade name, trademark, manufacturer, or otherwise does not necessarily constitute or imply its endorsement, recommendation, or favoring by the United States Government or any agency thereof. The views and opinions of authors expressed herein do not necessarliy state or reflect those of the United States Government or any agency thereof.

This report has been reproduced directly from the best available copy.

Available to DOE and DOE contractors from the Office of Scientific and Technical Information, P.O. Box 62, Oak Ridge, TN 37831; prices available from (423) 576-8401.

Available to the public from the U.S. Department of Commerce, Technology Administration, National Technical Information Services, Springfield, VA 22161, (703) 487-4650. 


\title{
DESIGN, CONSTRUCTION, AND OPERATION OF A LIFE-CYCLE TEST SYSTEM FOR THE EVALUATION OF FLUE GAS CLEANUP PROCESSES
}

\author{
By \\ Henry W. Pennline \\ James T. Yeh \\ James S. Hoffman \\ Edward J. Longton \\ Paul A. Vore \\ Kevin P. Resnik \\ Frederick N. Gromicko
}

December 1995

\author{
For \\ U.S. Department of Energy \\ Pittsburgh Energy Technology Center \\ P.O. Box 10940 \\ Pittsburgh, PA 15236
}

\author{
By \\ Pittsburgh Energy Technology Center \\ P.O. Box 10940 Pittsburgh, PA 15236 \\ and \\ Gilbert/Commonwealth Incorporated \\ P.O. Box 618 \\ Library, PA 15129





\section{TABLE OF CONTENTS}

$1.0 \quad$ ABSTRACT $\ldots \ldots \ldots \ldots \ldots \ldots \ldots \ldots \ldots \ldots \ldots \ldots \ldots \ldots \ldots \ldots \ldots \ldots \ldots$

$2.0 \quad$ INTRODUCTION AND BACKGROUND $\ldots \ldots \ldots \ldots \ldots \ldots \ldots \ldots \ldots$

3.0 DESIGN RATIONALE $\ldots \ldots \ldots \ldots \ldots \ldots \ldots \ldots \ldots \ldots \ldots \ldots \ldots$

$4.0 \quad$ SITE OF THE LCTS $\ldots \ldots \ldots \ldots \ldots \ldots \ldots \ldots \ldots \ldots \ldots \ldots$

5.0 DETAILED DESCRIPTION OF PROCESS AND EQUIPMENT $\ldots \ldots \ldots \ldots 7$

$5.1 \quad$ Flue Gas System $\ldots \ldots \ldots \ldots \ldots \ldots \ldots \ldots \ldots \ldots \ldots$

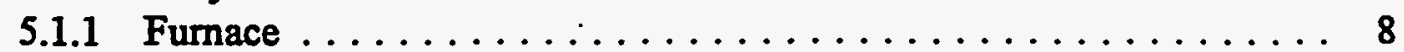

5.1 .2 Coal Feed System ................. 9

5.1.3 Combustion Air/Primary Air $\ldots \ldots \ldots \ldots \ldots \ldots \ldots \ldots, 10$

5.1 .4 Natural Gas Supply ....................... 11

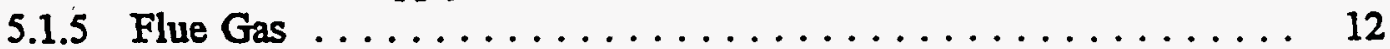

5.1.6 Absorber (Flue Gas Only) ................. 13

5.1 .7 Baghouse ....................... 14

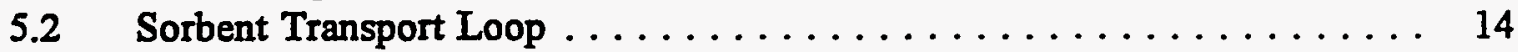

5.2.1 Absorber (Sorbent System) $\ldots \ldots \ldots \ldots \ldots \ldots \ldots \ldots \ldots \ldots \ldots$

5.2.2 Fluidized-Bed Heater $\ldots \ldots \ldots \ldots \ldots \ldots \ldots \ldots \ldots \ldots, 18$

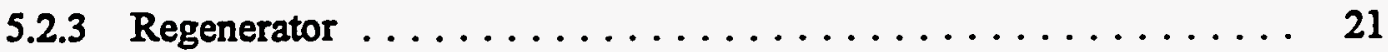

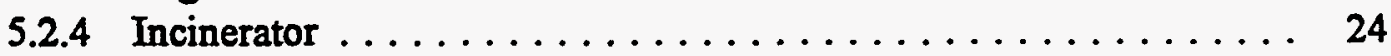

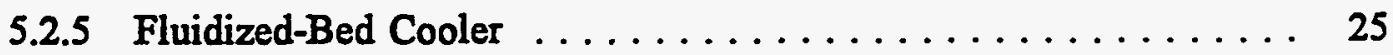

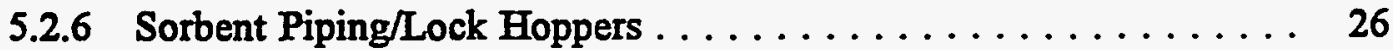

5.3 Instrumentation and Controls . . . . . . . . . . . . . . 29

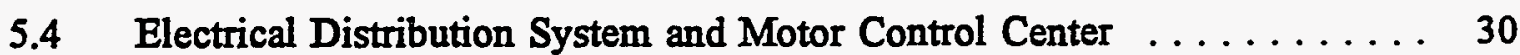

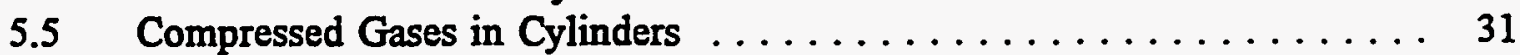

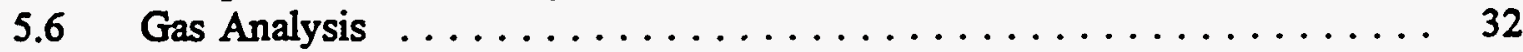

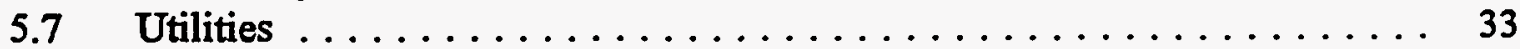

5.7 .1 City Water .......................... 33

5.7.2 Captive Cooling Water $\ldots \ldots \ldots \ldots \ldots \ldots \ldots \ldots \ldots \ldots \ldots$

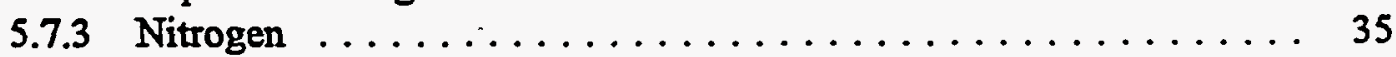

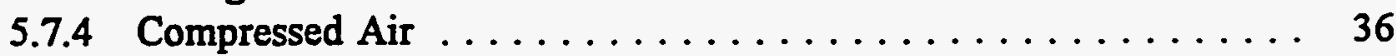

5.7 .5 Natural Gas ......................... 36

6.0 QUALITY ASSURANCE/QUALITY CONTROL $\ldots \ldots \ldots \ldots \ldots \ldots \ldots$

$7.0 \quad$ SHAKEDOWN RESULTS $\ldots \ldots \ldots \ldots \ldots \ldots \ldots \ldots \ldots \ldots \ldots \ldots \ldots$

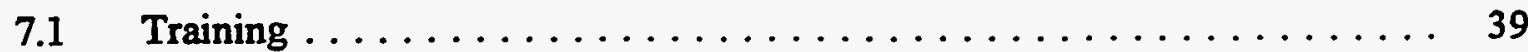

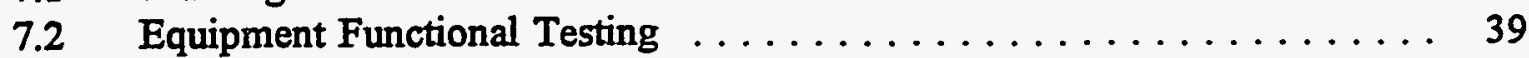

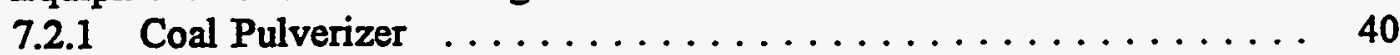

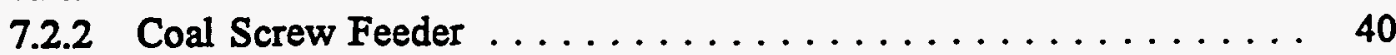

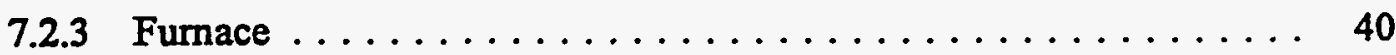

7.2.4 Flue Gas Coolers $\ldots \ldots \ldots \ldots \ldots \ldots \ldots \ldots \ldots \ldots \ldots \ldots$

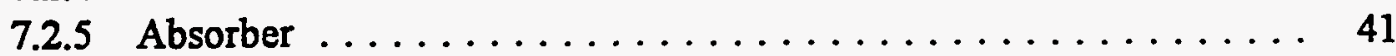




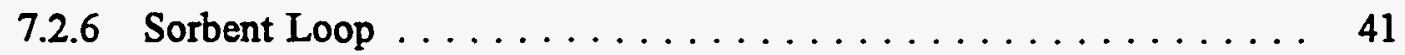

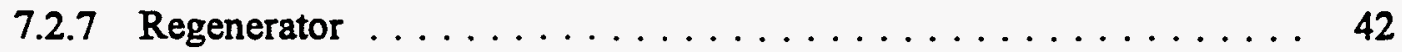

$8.0 \quad$ REFERENCES $\ldots \ldots \ldots \ldots \ldots \ldots \ldots \ldots \ldots \ldots \ldots \ldots \ldots \ldots \ldots \ldots \ldots$

$9.0 \quad$ ACKNOWLEDGEMENTS $\ldots \ldots \ldots \ldots \ldots \ldots \ldots \ldots \ldots \ldots \ldots \ldots$

10.0 DISCLAIMER $\ldots \ldots \ldots \ldots \ldots \ldots \ldots \ldots \ldots \ldots \ldots \ldots \ldots \ldots \ldots$

APPENDIX A: CALCULATED QUANTITIES AND MATERIAL BALANCES $\ldots \ldots .44$

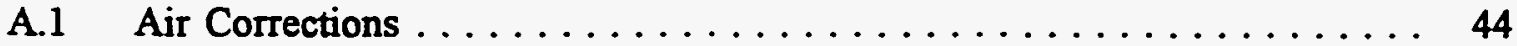

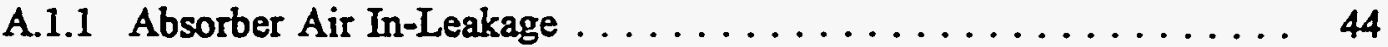

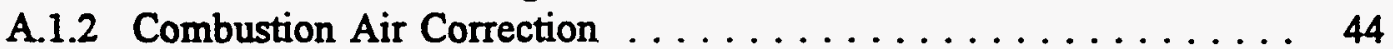

A.2 Equations for Data Analysis $\ldots \ldots \ldots \ldots \ldots \ldots \ldots \ldots \ldots, 48$

A.2.1 $\mathrm{SO}_{2}$ Removal Efficiency, $(\%)=\mathrm{E} 1 \ldots \ldots \ldots \ldots \ldots \ldots \ldots 48$

A.2.2 $\mathrm{NO}_{\mathrm{x}}$ Removal Efficiency, $(\%)=\mathrm{E} 2 \ldots \ldots \ldots \ldots \ldots \ldots \ldots$

A.2.3 Air-to-Cloth Ratio (Flue Gas to Absorber CS Area), $\mathrm{ft} / \mathrm{min}=$

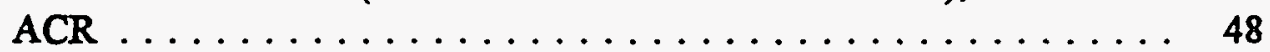

A.2.4 Apparent Gas Residence Time in Absorber, sec $=$ GRT $\ldots \ldots \ldots \quad 49$

A.2.5 Absorber Sorbent Residence Time, $\min =$ ART $\ldots \ldots \ldots \ldots .49$

A.2.6 Regenerator Sorbent Residence Time, $\min =$ RRT . . . . . 49

A.2.7 Fluidized-bed Cooler Sorbent Residence Time, $\min =$ CRT . . . . 49

A.2.8 Fluidized-bed Heater Sorbent Residence Time, $\min =$ HRT . . . . . 50

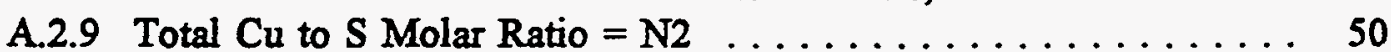

A.2.10 Available $\mathrm{Cu}(\mathrm{wt} \%)=\mathrm{N} 3 \ldots \ldots \ldots \ldots \ldots \ldots \ldots \ldots$

A.2.11 Available $\mathrm{Cu} / \mathrm{S}$ Molar Ratio $=\mathrm{N} 4 \ldots \ldots \ldots \ldots \ldots \ldots \ldots$

A.2.12 Moles $\mathrm{SO}_{2}$ Removed Per Mole Total $\mathrm{Cu}=\mathrm{N} 5 \ldots \ldots \ldots \ldots .52$

A.2.13 Moles $\mathrm{SO}_{2}$ removed per mole available $\mathrm{Cu}=\mathrm{N} 51 \ldots \ldots \ldots .52$

A.2.14 Lb Sorbent $/ 1000$ scf Flue Gas $=$ N6 $\ldots \ldots \ldots \ldots \ldots \ldots 53$

A.2.15 $\mathrm{NH}_{3} / \mathrm{NO}_{\mathbf{x}}$ Molar Ratio $=\mathrm{M1} \ldots \ldots \ldots \ldots \ldots \ldots \ldots$

A.2.16 Regenerator Methane to Sulfur Molar Ratio $=$ M2 . . . . . 54

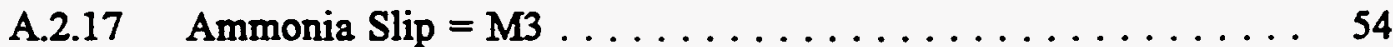

A.2.18 Sorbent Attrition, $\mathrm{lb} / \mathrm{cycle}=\mathrm{M} 4 \ldots \ldots \ldots \ldots \ldots \ldots \ldots \ldots$

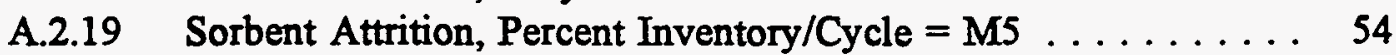

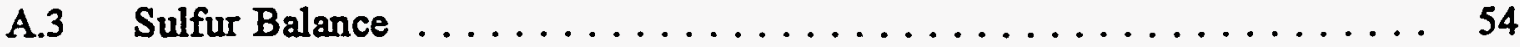

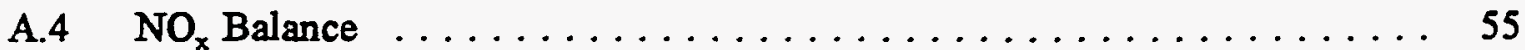

APPENDIX B: P\&IDS AND VESSEL DRAWINGS $\ldots \ldots \ldots \ldots \ldots \ldots \ldots \ldots . \ldots 6$

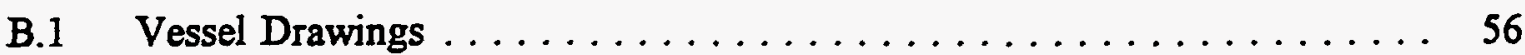

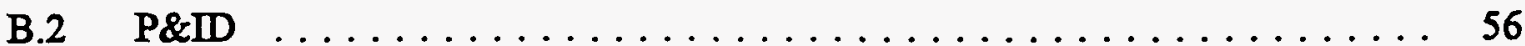

APPENDIX C: SORBENT TRANSPORT INFORMATION AND HOPPER CALIBRATIONS $\ldots \ldots \ldots \ldots \ldots \ldots \ldots \ldots \ldots \ldots \ldots \ldots \ldots \ldots \ldots \ldots \ldots \ldots$

\section{FIGURES}

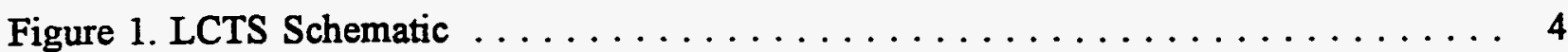

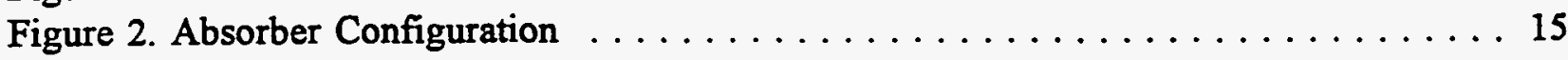




\subsection{ABSTRACT}

The Pittsburgh Energy Technology Center of the U.S. Department of Energy has designed, constructed, and operated a Life-Cycle Test System (LCTS) that will be used primarily for the investigation of dry, regenerable sorbent flue gas cleanup processes. Sorbent continuously cycles from an absorber reactor where the pollutants are removed from the flue gas, to a regenerator reactor where the activity of the spent sorbent is restored and a usable by-product stream of gas is produced. The LCTS will initially be used to evaluate the Moving-Bed Copper Oxide Process by determining the effects of various process parameters on $\mathrm{SO}_{2}$ and $\mathrm{NO}_{x}$ removals.

The purpose of this paper is to document the design rationale and details, the reactor/component/instrument installation, and the initial performance of the system. Although the Moving-Bed.Copper Oxide Process will be investigated initially, the design of the LCTS evolved to make the system a multipurpose, versatile research facility. Thus, the unit can be used to investigate various other processes for pollution abatement of $\mathrm{SO}_{2}, \mathrm{NO}_{x}$, particulates, air toxics, and/or other pollutants. 
The Pittsburgh Energy Technology Center (PETC) is pursuing pollution abatement research under many different programs established within the U.S. Department of Energy (DOE). The LifeCycle Test System (LCTS) provides an opportunity for technologies being developed under the Flue Gas Cleanup Program and the Advanced Combustion Program of DOE to be integrated, meeting the goals of both programs.

In response to the Title 1 and Title 4 sections of the Clean Air Act Amendments of 1990, the Flue Gas Cleanup Program of DOE initiated a subprogram entitled Superclean Emissions Control. The goal of this subprogram is to develop individual emissions removal rates of $99 \%$ and $95 \%$ for sulfur dioxide $\left(\mathrm{SO}_{2}\right)$ and nitrogen oxides $\left(\mathrm{NO}_{\mathrm{x}}\right)$, respectively, at a low cost [1]. This legislation also caused an increased interest in flue gas cleanup technologies that can effect combined removals of $\mathrm{SO}_{2}$ and $\mathrm{NO}_{x}$ from flue gas produced by the combustion of coal. One such technology is a dry, regenerable sorbent process that uses a supported metal oxide sorbent.

Concurrently with the Flue Gas Cleanup Program, the Advanced Combustion Program of DOE is developing advanced power systems to accelerate commercialization of economical, highly efficient, and low-emission coal-fueled electric generating technologies. A recent initiative from this program, called Combustion 2000, is designed to achieve dramatic improvements in the efficiency and environmental performance of future coal-fired power plants, while maintaining electricity costs at or below current levels. The two major components of the Combustion 2000 Initiative are the Low-Emission Boiler System (LEBS) and the High Performance Power System (HIPPS) [2]. Engineering development of these systems is in progress.

Dry, regenerable sorbent flue gas cleanup processes have been previously considered for conventional utility system applications. However, their unique design characteristics can make them quite technically and economically advantageous when integrated into advanced power systems, such as those pulverized-coal-fired systems defined in the DOE Combustion 2000 Initiative.

Several of these dry regenerable processes have been studied and are at various stages of development: the NOXSO Process, the Fluidized-Bed Copper Oxide Process, the Cerium Oxide Process, and the Sorbtech Vermiculite Process. Of particular interest is the Moving-Bed Copper Oxide Process, which is capable of simultaneously removing $\mathrm{SO}_{2}$ and $\mathrm{NO}_{x}$, meeting the goals of the Superclean Emissions Control subprogram, and being integrated into the design of advanced power systems [3]. This process has been the subject of experimental test programs at PETC and is currently being optimized using a moving-bed flue gas contactor. 
Although initial testing will entail the evaluation of the Moving-Bed Copper Oxide Process, PETC pursued the design of a generic Life-Cycle Test System (LCTS) that would be capable of evaluating various dry, regenerable sorbent processes in a continuous integrated mode of operation that includes sorbent regeneration. The LCTS that evolved is a multipurpose, versatile research facility. The system flow sheet is outlined in Figure 1. Not all process components shown will necessarily be used for testing a specific process, but they are available to meet the process conditions required for the several alternate regenerable supported metal oxide sorbents currently under consideration.

Design specifics of various vessels can be found in the following sections and in the literature [4]. The LCTS is designed to meet the following criteria:

(1) A wide range of process temperatures can be accommodated, including flue gas cooling and fluidized bed sorbent heating and cooling.

(2) Reactor vessels can easily be interchanged. For example, the reactor may be a cross-flow moving bed, a fluidized bed, a fixed bed, a countercurrent flow moving bed, or a new design.

(3) The flue gas flow entering the moving-bed absorber can be controlled in the range from $25 \%$ to $100 \%$ of the combustor output. This provides a wide range of process parametric study capability.

(4) A large regenerator will accommodate a range of sorbent residence times required for a desired level of sorbent regeneration. Sorbent residence time in the regenerator is a function of sorbent feed rate and the sorbent inventory in the regenerator.

(5) The materials of construction for certain high temperature processing vessels are designed for a maximum temperature of $1500^{\circ} \mathrm{F}\left(816^{\circ} \mathrm{C}\right)$.

The pertinent difference in the LCTS design compared to earlier studies performed at PETC is that a moving-bed absorber has replaced a fluidized-bed absorber. Because the lower pressure drop across the moving-bed configuration reduces power consumption, it strongly influences the overall economic costs. The moving-bed process also has a lower projected sorbent attrition rate compared with other reactor configurations. Lastly, high sorbent utilization (the degree to which the sorbent absorbs its theoretical maximum level of $\mathrm{SO}_{2}$ based on the metal oxide loading on the alumina sphere) can be realized in a moving-bed design. 


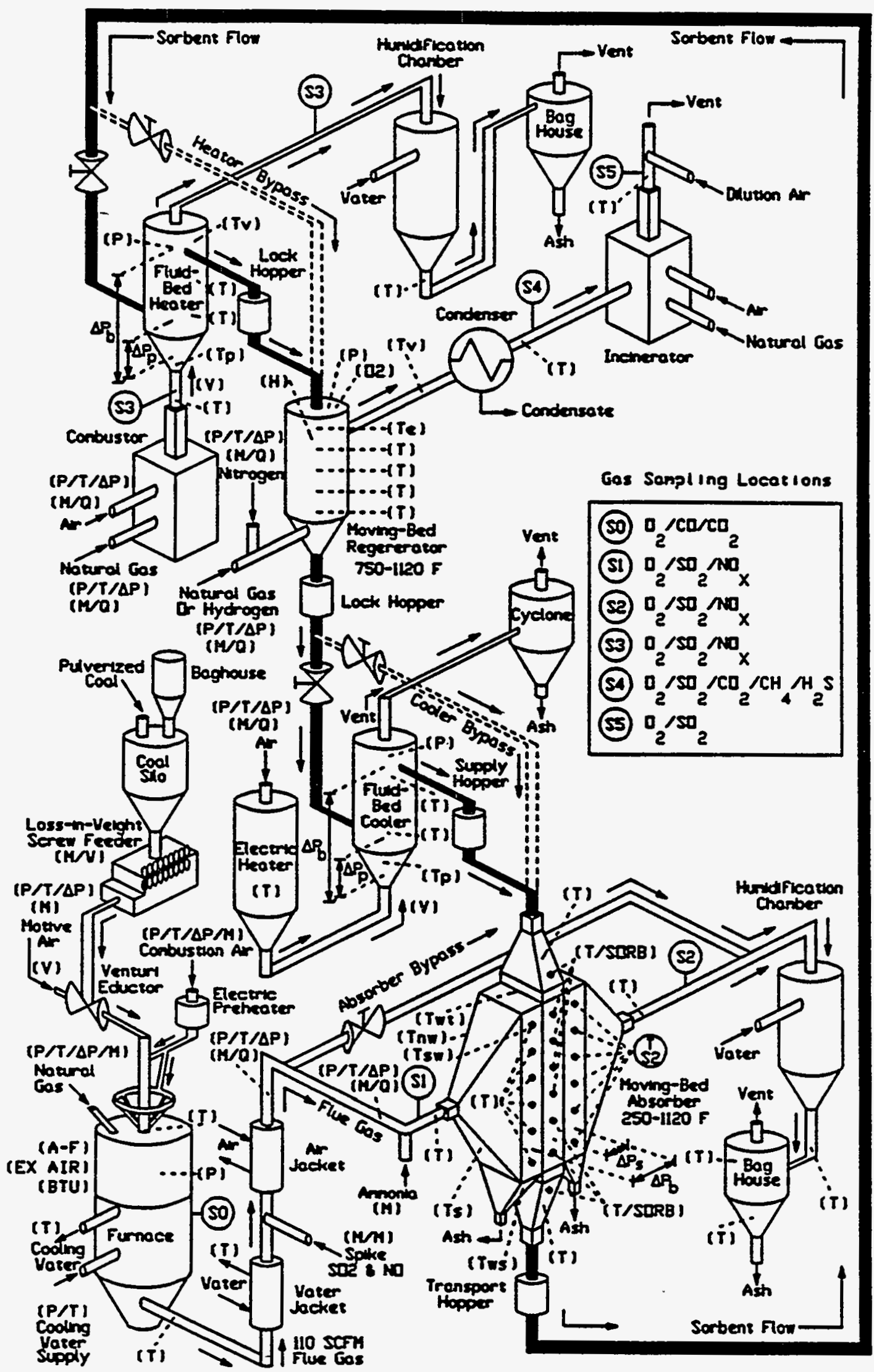

Figure 1. LCTS Schematic 
The LCTS is located in a platform on the east side of a highbay. The platform is a structural steel frame composed of three levels with open grating floors. The levels are connected by two stairwells, each with handrails. A catwalk connects the fourth level to an exit door into a transition area to provide alternative means of egress (less than $75 \mathrm{ft}$ ) from the platform.

All support equipment is located within or adjacent to the highbay, except for the coal pulverizer and site utilities. The coal pulverizer in an adjacent building is used to treat the raw coal that is then transported to the highbay through a 3-in pipe. Site utilities have been plumbed to the highbay, and distribution piping has been installed for the LCTS. The north end of the building contains utility rooms, including a motor control center and electrical distribution center. Blowers for the system are located on the roof.

Four compressed gas cylinder rooms are located outside the east side of the highbay at ground level. No cylinders would normally be contained within the highbay. Cylinders are segregated by hazard class, and the contents of each room are posted on the doors. Three of the rooms have their own source of heat, and each room has forced ventilation provided by an exhaust blower located on the roof of each room; fresh air makeup is through louvers in the access door to each room. Continuous ventilation is thus provided for each room. Each room has fire protection and explosion proof electrical equipment. Each room has ports for installation of plumbing, tubing, and conduit. Two of the rooms have ceiling explosion hatches that can be manually activated to open. These two rooms are designed for explosion protection and will house cylinders of flammable gases and calibration gases/inerts. The other rooms are reserved for oxidizers and toxic gases.

The LCTS control room is located on the ground level on the west side of the highbay. It has windows and its ventilation uses the highbay air. The gas analyzers are installed in the room above the control room, and this room is also ventilated with makeup air from the highbay. All sample gas from the analyzers are plumbed into a vent header which discharges above the roof of the building. The one exception is the regenerator exit-gas stream, which is sampled, analyzed, and then rerouted back to the exit stream.

The building is constructed of noncombustible materials: the floor is concrete, the walls are steel and brick, and the roof is steel and concrete. Wall penetrations into other areas, in particular the cylinder rooms, are sealed for fire protection and to prevent inleakage. Plumbing and conduit penetrate roof ports, which have been made weather tight.

Three large garage doors on the west of the building provide access for forklifts, truck deliveries, and emergency vehicles. Several doors into the highbay provide access for personnel. Access to the roof is by a stairwell; at the top is a hatch to the roof. On the roof, a set of stairs provides access to the utility platform where various blowers are located.

All process gases are plumbed to discharge above the roof of the building. The ventilation 
system provides sufficient ventilation for minor releases within the highbay. The building has been equipped with an HVAC system which has fresh air makeup at the north end and exhaust at the south end with no recirculation; the fresh air makeup can be heated with steam heat exchangers. The highbay has local hot water heaters that simply heat and circulate room air. The normal ventilation rate of the HVAC system was designed to provide four room changes per hour. The highbay ceiling has three exhaust blowers with their own louvers for emergency ventilation; design was to provide 16 changes per hour.

The building has a fire sprinkler system with sprinkler heads at the ceiling and local sprinklers at each landing of the platform. Portable fire extinguishers have been mounted throughout the highbay.

Lighting has been provided in the highbay and on each level of the platform. Emergency lighting, energized from an emergency generator, is available for each level to illuminate the path to each exit.

A 12-ton overhead crane services the building and has been used in the installation of the unit. The overhead crane is provided with a warning system to alert the crane operator if the crane may contact equipment. Jib cranes are located on each level except the top.

Fire alarms are in service and audible throughout the building. Also, gas detectors with alarms are installed in the highbay, and detectors are provided in the cylinder rooms containing toxic gases and flammable gases. 
The LCTS facility can be subdivided into two process functions: production and subsequent treatment of the flue gas, and sorbent transport and processing. (See Figure 1.)

Flue gas is generated by a combustor that burns approximately $40 \mathrm{lbs} / \mathrm{hr}(18 \mathrm{~kg} / \mathrm{hr})$ of pulverized coal, resulting in a nominal flue gas flow rate of $110 \mathrm{scfm}(3115 \mathrm{slpm})$. Coal is pulverized in an adjacent building, stored in a 20-ton hopper, periodically transported to the LCTS feed silo, and fed from the silo by a feed screw into a stream of transport air for combustion in the furnace. The combustor can also be fired using natural gas for purposes of preheating the absorber and associated vessels, thus preventing condensation of corrosive flue gas components, such as sulfuric acid, during initial coal burning.

The flue gas exiting the combustor passes through heat exchangers so that a prescribed inlet absorber temperature can be maintained. The flue gas can be spiked with $\mathrm{NO}$ and $\mathrm{SO}_{2}$ supplied from cylinders to adjust these concentrations to those of the desired test levels. Depending on the sorbent investigated, ammonia can be injected into the flue gas upstream of the absorber to facilitate the catalytic reduction of nitrogen oxides to nitrogen and water vapor in the absorber. A controlled flue gas bypass provides a slip stream around the absorber, enabling the desired flow of flue gas through the absorber to be maintained. After passing either through or around the absorber, the flue gas is cooled by humidification and then passed through a baghouse for removal of any residual fly ash.

The sorbent process stream involves a closed-loop cycle of sorbent transported through four major vessels. The sorbent absorbs flue gas contaminants $\left(\mathrm{SO}_{2}, \mathrm{NO}_{x}\right)$ in an absorber, passes through a fluidized-bed sorbent heater where it is heated with air and the products of a natural gas combustor, enters a regenerator where it is treated with a reducing gas and gaseous sulfurcontaining species are released, and passes through a fluidized-bed air cooler prior to returning to the absorber. The sorbent is gravity fed through all four vessels, with the exception being the line connecting the absorber exit with the fluidized-bed sorbent heater. In this line, a pneumatic transport system sends the sorbent to an elevated location (i.e., the sorbent heater) to repeat the gravity-fed sorbent cycle. The hot air from the sorbent heater is vented through a baghouse for dust removal, and the regenerator offgas is vented through an incinerator.

The entire system operates at pressures close to ambient; the various vessel pressures are maintained by forced draft and induced draft blowers and control valves. Currently, the sorbent system operates at temperatures ranging from 700 to $1100^{\circ} \mathrm{F}\left(371\right.$ to $\left.593^{\circ} \mathrm{C}\right)$. The absorber and regenerator have externally mounted heaters for temperature maintenance.

As previously mentioned, the absorber can be of various designs, and initial plans call for the moving-bed design to be used in the investigation of the Moving-Bed Copper Oxide Process. Both sorbent performance and operational performance will be optimized to obtain the extremely high emissions control goals of the Flue Gas Cleanup Program. 


\subsection{Tlue Gas System}

\subsubsection{Fumace}

This furnace, which was previously used to support the NOXSO testing program, has a capacity of $650,000 \mathrm{BTU} / \mathrm{hr}$. It can be operated on $40-\mathrm{lb} / \mathrm{hr}$ pulverized coal or $20-\mathrm{lb} / \mathrm{hr}$ natural gas or a combination of both to generate approximately 110 $\mathrm{scfm}$ of flue gas. The flame temperature is approximately $2000^{\circ} \mathrm{F}$; the flue gas exit temperature is approximately $1500^{\circ} \mathrm{F}$.

The furnace is installed vertically with the burner at the top. The shell is fabricated from 30-in diameter, 3/8-in thick steel pipe, approximately $10 \mathrm{ft}$ long. It is protected by a refractory lining in the combustion section and has externally mounted water-cooled panel coils. The burner mounting flange is refractory lined, and all furnace penetrations are protected by water-cooling coils.

The natural gas pilot can be lit directly from an igniter. Once a flame is confirmed, the igniter is deenergized. The coal feed is started only after a natural gas flame has been established. One flame detector monitors both the gas and coal flames. The flame supervisory system has been designed to comply with the National Fire Protection Association (NFPA) standards for the prevention of explosions in combustion systems which burn either coal, natural gas, or both. Before any conditions are created which could result in an explosion, all fuels to the furnace will be automatically shut off.

When coal or natural gas is being burned, the combustion air can be preheated up to $600^{\circ} \mathrm{F}$. This air is supplied both tangentially and axially and can be adjusted for combustion optimization in the following manner. A dilute phase of pulverized coal in air flows through an inner tube in the burner. A controlled stream of air flows axially around the coal feed tube. Air is also supplied through four tangential ports at the burner. The amount of swirl can be varied by adjusting the proportion of mass flow rates of air flowing tangentially and axially.

The combustion products exit the side of the furnace bottom cone. An ash pit on the bottom cone is emptied periodically. The flue gas velocity is sufficient to prevent any ash accumulation within the flue gas plumbing.

A safety alarm and shutoff system prevents dangerous conditions from developing in the furnace. The furnace must be purged with air prior to initiating the flame startup sequence at the beginning of the test and as a result of any flame failures. A minimum of $20 \%$ of the full-load air must be maintained during combustion or all fuel will be shut off to prevent fuel rich conditions. All fuel will be isolated as a result of any flameouts. The natural gas supply has both high pressure and low pressure trips to prevent fluctuations from resulting in explosive conditions. 
The coal feed cannot be initiated unless a natural gas fire and combustion air flows have been established and the combustion air temperature is at least $500^{\circ} \mathrm{F}$. Because coal flames are not as stable as gas fires, a flame detector time delay has been provided to eliminate nuisance trips which could result from minor fluctuations in the coal feed flow. The time delay will be limited to 15 seconds.

A high-temperature flue gas alarm is provided. Flue gas temperature and all cooling water outlet temperatures are measured and documented to establish a profile. The refractory lined portion of the furnace has been cured, and the furnace shell is protected by water cooling panel coils externally mounted to the shell. Failures of the cooling water system causing low water flow, low pressure, or high water return temperature will result in fuel shutoff to the furnace. The furnace operates at a slight negative pressure and is a closed system. The flue gas system pressure is measured and controlled; the furnace has a high-pressure shutdown.

\subsubsection{Coal Feed System}

Coal is pulverized to approximately $80 \%$ through a 200 -mesh sieve and dried to less than $2 \%$ moisture content. The coal is stored in a 20 -ton hopper and then transferred as needed to the $78-\mathrm{ft}^{3}$ silo at the LCTS.

The silo is fabricated of steel and is designed for a positive pressure of $5 \mathrm{psig}$; it has a baghouse. The silo is equipped with a rupture disc set for 22 -in WC. The silo atmosphere is kept inert by a continuous nitrogen purge and when in use, the baghouse is pulsed with nitrogen. The baghouse is vented to the atmosphere above the roof; the bags have differential pressure measurement to indicate when they are caked. The coal plumbing and equipment are all grounded and bonded to prevent any accumulation of static.

During normal operation, the silo typically requires refilling once every three days. The silo has a low-level alarm to alert operators when coal is required and a highlevel alarm to warn personnel when it is nearly full. The high-level alarm is set to allow sufficient clearance in the silo for the coal feed to be shut off and the transport pipe to be blown clean. When coal is being transferred, personnel use a communication system to aid in shutting off the coal feed when the silo high level alarm is activated in order to prevent overfilling of the silo.

The coal is transported to the test platform through a 3-in diameter steel pipe from the coal preparation equipment using nitrogen as the transport medium. Nitrogen flow is sufficient to maintain the transport velocity to prevent deposition of the coal in the piping. Any low flow or fluctuation may result in plugging of the piping. 
A loss-in-weight screw feeder is located at the bottom of the silo. Coal from the feeder is transported by air to the furnace. The coal feed from the silo has isolation valves to shut off the coal feed as a result of any furnace shutdown or loss of transport air flow. The silo also has a vibrator and nitrogen purges in the bottom cone to help prevent coal from plugging inside the silo.

From the feeder, the coal transport piping is $1 / 2$-in stainless steel tubing. A minimum air flow is required to maintain the coal velocity to prevent deposition within the piping. If the furnace shuts down, the transport air will remain in service for sufficient time to sweep any coal from the transport piping. Should the coal feed plug to the furnace, means are provided to prevent air from flowing up into the silo. The transport air flowing through an eductor draws the coal from the feeder into the transport piping. The coal feed rate, combustion air, and natural gas flow are all used to maintain proper fuel air ratios and limit the maximum heat into the furnace.

\subsubsection{Combustion Air/Primary Air}

Two sources of air are used for combustion during coal firing: the instrument air system provides coal transport air, and a forced draft blower provides secondary combustion air. Approximately $18 \mathrm{lb} / \mathrm{hr}$ of dried instrument air is used to transport the pulverized coal to the furnace burner and to cool the burner during gas firing.

The forced draft blower is located on the roof. This blower has a capacity of 300 scfm and provides air to the following: secondary combustion air, the burner gas pilot, purging of the furnace sightglass and pilot tube, and air cooling in a flue gas cooler. The blower has a maximum discharge pressure of 107-in WC. It was used to leak check the furnace and flue gas system during shakedown tests prior to insulating the system.

An electric heater which operates on 480 volts preheats the secondary air up to $600^{\circ} \mathrm{F}$. The air flow and temperature are measured and controlled. The secondary air, which enters the burner axially and tangentially, must be manually adjusted by viewing the combustion to optimize the flame. The heater cannot be energized unless air is flowing; it also has a high temperature shutdown switch to prevent damage due to overheating.

The furnace pressure is controlled at approximately -0.5-in WC using two in-line induced draft blowers that are connected in series. If the blowers or control fail, the furnace has high pressure protection and fuel shutoffs.

Streams of air from the combustion air blower also are used for other purposes. One stream is used for gas pilot air, which remains flowing during furnace 
operation to cool and purge the pilot tubing. Another stream purges the sightglass to cool it and to prevent ash/soot from fouling the viewport. A third stream of air is used to cool the UV detector port. These latter two flows are measured and can be manually adjusted.

A slip stream of the compressed air up to approximately $125 \mathrm{scfm}$ at ambient temperature is also used for the cooling medium in a flue gas heat exchanger; this flow is controlled by a flue gas temperature controller.

\subsubsection{Natural Gas Supply}

The natural gas is supplied to various parts of the system from a 1-in, schedule 40 steel header in the highbay which is connected to the site 15 psig natural gas header. The header supplies natural gas to the following: the furnace, the regenerator, the incinerator, and the fluidized-bed air heater. Only the furnace usage will be discussed in detail here; the other uses will be discussed in the respective sections on the other equipment.

The natural gas is used for a gas pilot and coal-burning support. The furnace can also be operated solely on gas fire. The gas flow to the furnace for combustion is maintained between 3.2 and $25 \mathrm{lb} / \mathrm{hr}$ at 2 to $7 \mathrm{psig}$. The gas supply pressure and flow are both measured and controlled. If the design parameters are exceeded, the supply is automatically shut off to prevent possible explosive conditions within the furnace. The maximum flow is also physically limited by a restricting flow orifice. Whenever the supply to the furnace is automatically shut off, or the furnace is shut down, the natural gas supply is isolated by two shutoff valves that have a vent to atmosphere between them.

The furnace utilizes a spark igniter, which is deenergized after a timed period, to initiate a gas pilot. The pilot is then used to ignite a main gas flame, which can be used independently of a coal flame or as a coal support flame. Prior to establishing any combustion or after any flameouts, the furnace is purged with air to remove any unburned fuel which could create an explosive mixture.

The piping was pressure tested and leak checked prior to being charged with natural gas. The supply from outside the highbay is identified so that it can be quickly shut off in the event of a release in the highbay. The site supply header has redundant pressure control and its own pressure protection. Because all natural gas equipment at the LCTS is designed for at least 15 psig service, pressure protection on the natural gas supply within the highbay has not been provided. 


\subsubsection{Flue Gas}

During normal operation, approximately $110 \mathrm{scfm}$ of flue gas exits the furnace at $1200^{\circ} \mathrm{F}$; this is cooled to between 700 and $900^{\circ} \mathrm{F}$ for the first process to be tested, using an air-cooled heat exchanger upstream of the absorber. A water-cooled heat exchanger also is available if additional cooling is required. Ammonia, $\mathrm{SO}_{2}$, and NO from cylinders can be added to the flue gas upstream of the absorber to adjust the $\mathrm{SO}_{2}$ and $\mathrm{NO}$ content for testing. The flue gas plumbing is designed for $1200^{\circ} \mathrm{F}$ and 5 psig.

Some ash in the flue gas is collected in the ash pit at the bottom of the furnace, some is removed in the absorber, and the remainder is collected in a baghouse before the flue gas is discharged to the atmosphere above the roof of the building. Prior to entering the baghouse, the flue gas is cooled to about $385^{\circ} \mathrm{F}$ using a humidification chamber with a water spray. The velocity in the flue gas piping is sufficient to prevent any accumulation of particulate. Excessive water spray in the humidifier could result in some flyash knockout, but controls are in place to shut off the water when cooling is not required. Normally, all the water is vaporized.

The furnace operates at a slight negative pressure produced by two induced draft blowers in series located on the roof and downstream of the baghouse. The absorber and baghouse both have plumbing so that the flue gas can bypass these subsystems during startup, shutdown, or when firing with natural gas. The absorber bypass normally is used as a control to maintain a constant flow of flue gas to the absorber.

The flue gas piping is fabricated from 3-in schedule 10 stainless steel pipe with flanged and welded connections. The first heat exchanger upstream of the absorber consists of a double-pipe design using treated water for the cooling medium. The water flow, temperature, and pressure are measured and controlled; low flow or pressure, or high water temperature will trigger a furnace shutdown. The water system also has high pressure protection. The second heat exchanger upstream of the absorber is also a jacketed pipe which uses a slip stream from the ambient combustion air blower as the cooling medium; this air flow is controlled by a flue gas temperature controller. The third flue gas cooler, located between the absorber and the baghouse, utilizes a spray of city water into the flue gas passing in a humidification chamber. The water is atomized with instrument air in a dual fluid nozzle to humidify and thus cool the flue gas; the water and air flows and the flue gas temperature are controlled. The furnace fuels are shut off if the baghouse flue gas temperature exceeds $450^{\circ} \mathrm{F}$.

Typically, the flue gas entering the absorber contains approximately 4-lb/hr of flyash, 3 to $5 \%$ oxygen, nitrogen, $\mathrm{CO}_{2}$, some $\mathrm{CO}, 300$ to $1000 \mathrm{ppm} \mathrm{NO}, 1500$ to 
$4500 \mathrm{ppm} \mathrm{SO}$, and some ammonia. The temperature will be maintained above the dewpoint to minimize any corrosion. The plumbing was pressure tested and leak checked prior to firing the furnace and normally operates at a slight negative pressure. If the baghouse plugs, the plumbing may experience a maximum of 100 -in WC, although the absorber inlet pressure safety valve would limit this to 40-in WC.

Cylinders of compressed gas $\left(\mathrm{SO}_{2}, \mathrm{NO}\right.$, and $\left.\mathrm{NH}_{3}\right)$ supply the injection gases. These are located in the highbay cylinder rooms. Each has its own plumbing system with flow and pressure measurement, control, pressure protection, and purge capability.

\subsubsection{Absorber (Flue Gas Only)}

A flow of approximately $110 \mathrm{scfm}$ of flue gas at a desired temperature (typically 700 to $900^{\circ} \mathrm{F}$ for the initial scheduled testing) is maintained into the absorber and through the sorbent bed where the $\mathrm{SO}_{2}$ and $\mathrm{NO}_{\mathrm{x}}$ will be removed. $\mathrm{NO}, \mathrm{NH}_{3}$, and $\mathrm{SO}_{2}$ are injected into the flue gas upstream of the absorber to adjust the NO and $\mathrm{SO}_{2}$ concentrations established by the test conditions. Some ash is removed in the absorber. The flue gas components are analyzed by continuous emissions monitoring before and after the absorber. The absorber bypass and a butterfly valve located on the flue gas downstream of the absorber can be used to direct flue gas around the absorber during startup and shutdown and to maintain a constant flow through the absorber.

The absorber is designed for $1200^{\circ} \mathrm{F}$ and -40 -in WC; it normally operates at a slight negative pressure of -5 -in WC. The flue gas plumbing has a pressure-switch activated valve upstream set at 40 -in WC, and a vacuum breaker downstream of the absorber set at -40-in WC. Failures due to pressure or temperature upsets will be extremely unlikely. The absorber was leak tested by the fabricator, and it and all the plumbing in the flue gas system were pressure checked in situ. The absorber will be disassembled periodically to change, repair, or modify the screens and the system, and then leak tested after reassembly and prior to startup. The absorber shell has electric heat tracing arranged into five zones, each of which has its own temperature measurement and control. Four electric zones heat the flanged area of the absorber, and one zone heats the gas entrance section. Skin thermocouples welded to the structure in the zones are used for control and monitoring. Set points are currently upper-limited to $1000^{\circ} \mathrm{F}$. Thermocouples also extend into the sorbent bed at six height locations and are used to obtain flue gas temperature profiles during operation. The absorber bottom has two ports -- one on the flue gas inlet and one on the exit -- from which ash and sorbent dust can be removed during operation. 


\subsubsection{Baghouse}

Flue gas exits the absorber at 700 to $900^{\circ} \mathrm{F}$, is cooled to approximately $385^{\circ} \mathrm{F}$ by a water spray in a humidification cooler, and then enters the baghouse where flyash and sorbent dust, if any, are removed. The baghouse shell is constructed of carbon steel and has nine NOMEX bags that are 54 in long by 6 in in diameter. The bags are designed for a maximum working temperature of $400^{\circ} \mathrm{F}$ with a limit to $450^{\circ} \mathrm{F}$. Two blowers in series are located on the roof and provide an induced draft.

A high-temperature trip set at $450^{\circ} \mathrm{F}$ prevents damage to the baghouse from overheating. Procedures require bypassing the baghouse if the temperature is below $250^{\circ} \mathrm{F}$ to prevent corrosion that may result from condensation if the flue gas is too cold. During each shutdown, the baghouse is purged of flue gas using air after the furnace combustion has been stopped.

The baghouse pressure can range from a negative pressure of -70-in WC up to 32in WC, the latter case occurring if the forced draft air blower fails. The system pressure is controlled upstream of the baghouse by a pneumatically operated control valve. The bags are periodically pulsed with nitrogen. Three pulse valves are controlled by a local timer; the duration of the pulse, the time between pulses, and the cycle are set. Each pulse valve directs a short burst of nitrogen between 50 to 125 psig to three of the bags. The baghouse also has a nitrogen purge which can be manually used and which is automatically actuated as a result of high temperature. The bags have differential pressure measurement to indicate plugging. The baghouse is designed for approximately 5 psig.

Ash that accumulates in the bottom of the baghouse will be collected during operation by periodically opening a valve at the bottom and draining the ash into a hopper. The baghouse has a bypass and a valve on the inlet that can be closed to stop the flow of flue gas; the baghouse has the option of being bypassed when the furnace is fired on natural gas.

\subsection{Sorbent Transport Loop}

\subsubsection{Absorber (Sorbent System)}

The purpose of the absorber is to provide a place where sorbent can come in contact with the flue gas in order to remove the $\mathrm{SO}_{2}$ and $\mathrm{NO}_{\mathrm{x}}$. Depending on the mesh size of the screens employed, ash can also be removed. Depicted in Figure 2 is a 11.5-ft high, 9.3-ft long, and 2.5-ft wide absorber. It is constructed of $316 \mathrm{~L}$ stainless steel and is designed for $1200^{\circ} \mathrm{F}$ and a pressure of $+/-40$-in $\mathrm{WC}$ in an atmosphere containing $\mathrm{SO}_{2}$ and $\mathrm{NO}_{\mathrm{x}}$. 

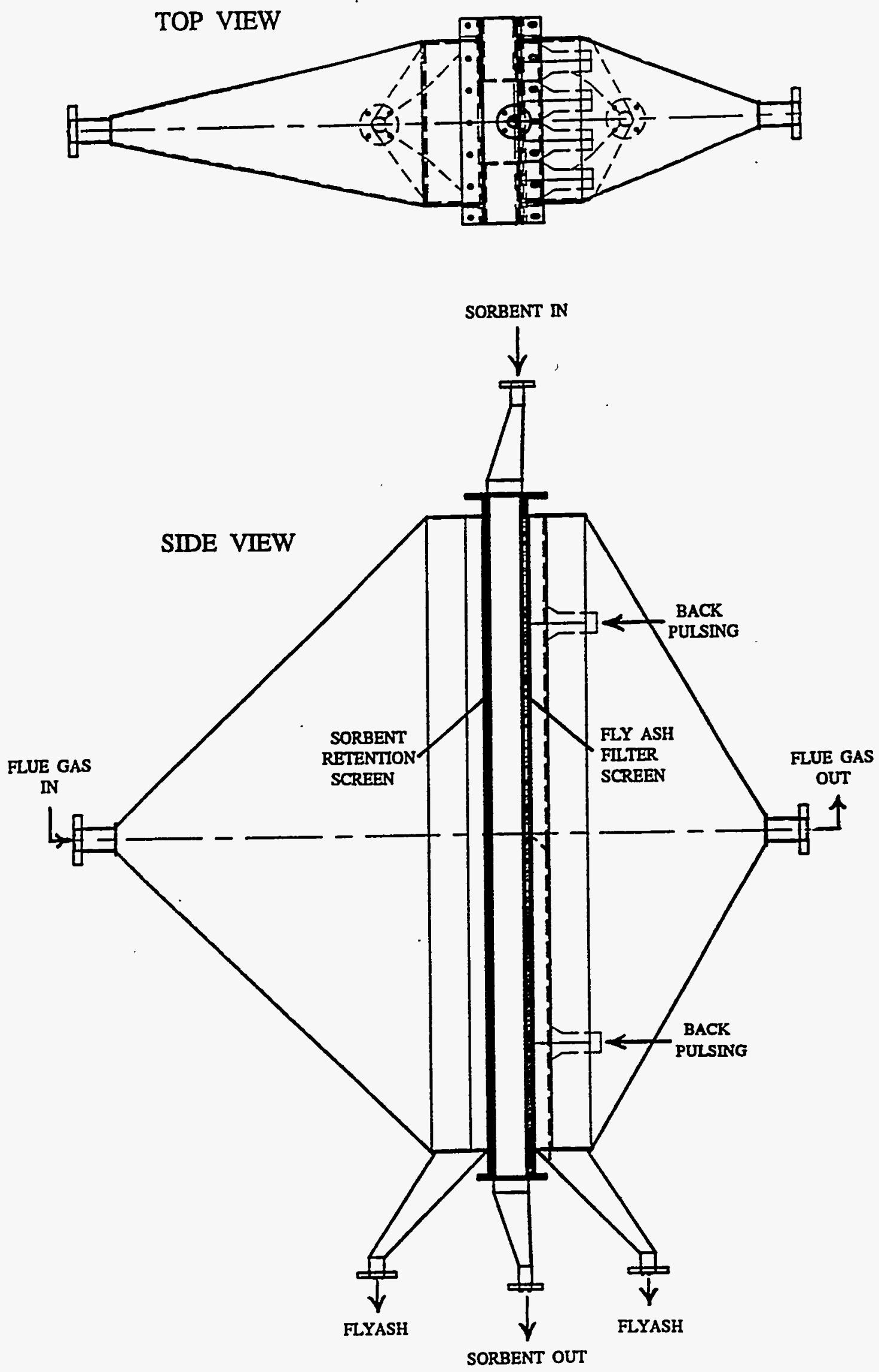

END VIEW

(FROM FLUE GAS EXIT)

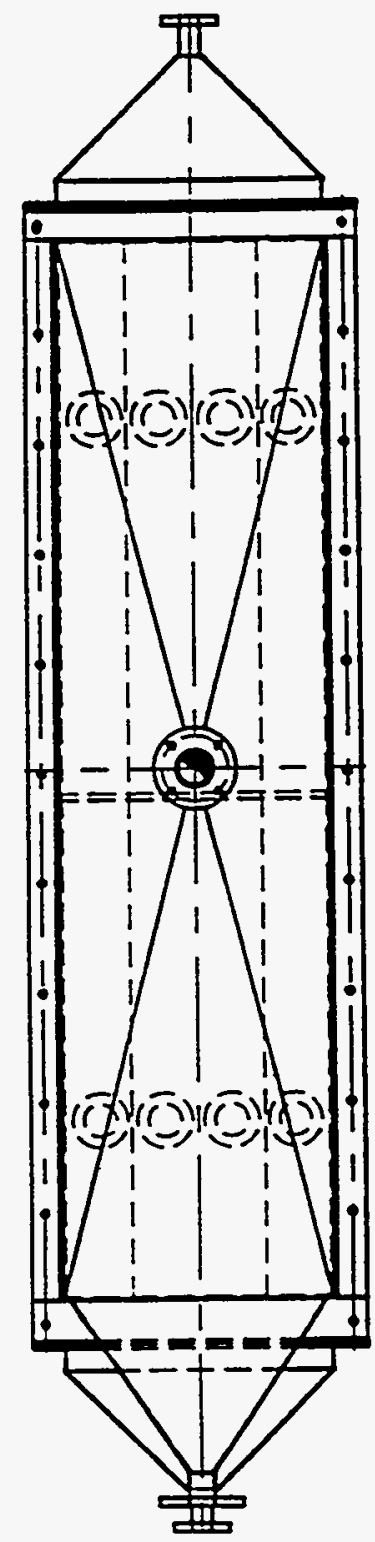

Figure 2. Absorber Configuration 
The absorber has two retention screens to hold the sorbent bed in place. Each retention screen is made of a 1/8-in thick stainless steel plate with 1-in holes drilled on 1.25-in staggered centers. A 316 stainless steel square weave wire cloth is stitch-welded to the perforated plate around the perimeter and tack-welded at a few locations in the middle of the 2-ft by $8-\mathrm{ft}$ area. The wire cloth is 35 mesh with 0.0176 -by-0.0176-in square openings, 0.022 -in thick, and has $37.9 \%$ open area. These retention screens can be adjusted to change the sorbent bed depth from 1 to 12 -in and blanked off to adjust the bed width to 12 or 24 -in, dependent upon the test parameters specified.

Screen mesh sizes are selected to allow flue-gas-entrained flyash to pass through the bed, or be filtered out at either the bed front or the bed rear. The rear screen area is divided into eight equal areas by a pulser box assembly located immediately downstream of the screen. Flue gas passing through the screen flows into eight plenums formed by the box. The screen area covered by each plenum is sequentially cleaned by a reverse flow burst of nitrogen or air delivered by a pulse valve, nozzle, and venturi. Presently, compressed air is used for pulsing. A cyclic timer can activate all eight pulse valves in rapid sequence, with a threesecond minimum interval between each valve. Individual or any combination of valve pulsings can be conducted, and the frequency and duration of pulses also can be varied. The timer is activated by either a hand switch at the ground floor I/O panel or the personal computer system (PCS) in response to the pressure drop across the rear screen. Ash is collected in hoppers built into the flue gas inlet and outlet cones.

Normal bed width is 24-in. However, the width of the bed can be reduced to 12in by assembling the absorber with different bed side-walls. Doing this effectively blocks the outside plenums in the pulser box assembly.

Regenerated sorbent from the fluidized-bed cooler passes through the moving bed inside the absorber where it comes in contact with flue gas, which is also passing through the bed. Proper sequencing of the flows from the hoppers into and out of the absorber assures that the bed and the inlet cone are full of sorbent during the testing. For the initial investigation of the Moving-Bed Copper Oxide Process, $\mathrm{SO}_{2}$ and $\mathrm{O}_{2}$ in the flue gas combine with supported copper oxide to form $\mathrm{CuSO}_{4}$ on the sorbent. The $\mathrm{CuSO}_{4}$ also catalyzes the formation of $\mathrm{N}_{2}$ and water vapor from the $\mathrm{NO}_{\mathrm{x}}, \mathrm{O}_{2}$, and $\mathrm{NH}_{3}$ in the flue gas. (Ammonia is injected into the flue gas stream ahead of the absorber.) Gas analyzers are used to measure the concentrations of $\mathrm{SO}_{2}, \mathrm{NO}_{\mathrm{x}}$, and $\mathrm{O}_{2}$ in the flue gas as it moves into and out of the absorber.

The sorbent inlet temperature is maintained at 700 to $900^{\circ} \mathrm{F}$, depending on the desired initial testing requirements. The sorbent flows from top to bottom by gravity at a controlled flow rate that can be set to approximately 0.65 to $3 \mathrm{lb} / \mathrm{min}$, 
depending on the parameters specified in the testing. Sorbent from the bottom of the absorber is transported to the fluidized-bed heater using compressed air in a valve-sequenced transport hopper. The sorbent system is isolated from the absorber by lock hoppers. (See Appendix C.)

The flue gas flow to the absorber normally is $110 \mathrm{scfm}$ and can be controlled by using a bypass around the absorber to divert excess flow. The flow control provides flexibility for changing various parameters related to sorbent or gas residence time. During initial testing, the temperature of the flue gas is controlled at 700 to $900^{\circ} \mathrm{F}$ by cooling the gas in the preceding heat exchangers. The flue gas pressure is maintained at a slight vacuum by induced draft blowers downstream of the absorber. The absorber has high pressure protection set at 40-in WC on the inlet and a vacuum breaker set at -40 -in WC on the outlet.

The absorber has five controlled heating zones that use electric heat tracing; the absorber skin temperature is measured and used to control the electric heaters; the controllers will be limited to $1000^{\circ} \mathrm{F}$. The absorber flue gas inlet cone has WATLOW FIREBAR heating units of specific lengths, voltages and watt densities. The units are flat, about 1 -in wide, and are mounted in contact with the vessel skin. All heating elements within a zone are wired in parallel so that operation is possible even if an element should burn out. The absorber flue gas inlet cone is powered and controlled as one zone. The absorber bed flanges are heated by Watlow Multicell 480 VAC 3-phase elements. Two lengths are employed: 96-in heated lengths for the vertical flanges and 30-in heated lengths for the horizontal flanges. Heat transfer to the flanges is primarily by radiation. Shields surrounding the elements keep most of the energy directed at only the flanges. The bed flanges are divided into four zones: absorber south side, absorber north side, absorber top, and absorber bottom. All heating elements within a zone are wired in parallel. If the flue gas temperature to the absorber exceeds $950^{\circ} \mathrm{F}$, the furnace will shut down.

The absorber will be operated for long periods at elevated temperatures and will be periodically disassembled to change screens. Because the flange studs can seize and the screens and support frames can become distorted, the absorber is periodically leak checked during system startup by monitoring the inlet and outlet oxygen content.

The flue gas concentration is adjusted to 1500 to $4500 \mathrm{ppm} \mathrm{SO}_{2}$ and 500 to 1000 ppm $\mathrm{NO}_{x}$ by the addition of $\mathrm{SO}_{2}$ and $\mathrm{NO}$, respectively, upstream of the absorber. Ammonia can be injected into the inlet flue gas to facilitate the $\mathrm{NO}_{\mathrm{x}}$ removal, but this is a function of the type of sorbent used in the cleanup process. The flue gas is analyzed by using continuous emissions monitors at the inlet and outlet of the absorber. 
The flue gas nominally contains up to $4-\mathrm{lb} / \mathrm{hr}$ of flyash, dependent upon the ash content of the coal burned. The absorber has ash removal ports at the bottom that will remove settled dust. Any sorbent dust or ash that accumulates will be collected in portable containers connected to nozzles on the absorber. The sorbent retention screens have the capability of being pulsed by nitrogen or air in the event of ash buildup on the screen. Hazardous materials are purged from the absorber and gases are cooled during shutdown. The absorber and piping are grounded and bonded to dissipate any static charge that may accumulate due to the sorbent flow.

\subsubsection{Fuidized-Bed Heater}

The purpose of the fluidized-bed heater is to provide a source of hot gas with which to fluidize and heat the sorbent coming from the absorber to the process temperature of the regenerator. The fluidized-bed heater is one of the main sources of heat for the sorbent. Sorbent cannot be transferred through it until the bed has reached a temperature of $\sim 200^{\circ} \mathrm{F}$. The temperature in the bed of the fluidized-bed heater will be somewhat higher than the regenerator process temperature because of the heat loss during sorbent transport to the regenerator.

The system that supports the fluidized-bed heater consists of an air heater, blower, humidification chamber, and baghouse. Sorbent is moved to the fluidized-bed heater from the absorber by an air pressurized transport hopper.

The fluidized-bed heater is a vertical vessel with three basic sections. Hot gas from the air heater comes into the bottom inlet plenum and then passes into the middle fluidized-bed section through "J" tubes mounted in a distributor plate which separates the two sections. The evenly distributed gas promotes good sorbent fluidization and heat transfer. The vessel expands to a larger cross-section above the bed, slowing the gas velocity down and allowing the larger sorbent particles to stay behind. Ash and sorbent fines are carried out the top of the disengagement zone to the fluidized-bed heater baghouse where they are filtered out. The hot exhaust gas is cooled by water spray injection in the humidification chamber prior to entering the baghouse. Gas analyzers are used to measure the concentration of $\mathrm{SO}_{2}, \mathrm{NO}_{x}$, and $\mathrm{O}_{2}$ in the air stream to and from the fluidized-bed heater.

The air heater consists of a combustion chamber equipped with a gas-fired burner. A Spencer blower on the roof operating at $\sim 6$ psig provides combustion air as well as cooling air. Gas from the air heater fluidizes and heats the bed of sorbent in the fluidized-bed heater.

The humidification chamber is a long, vertical vessel that contains an air atomizing water nozzle. It injects a fine water spray and thereby cools the exhaust 
gases from the fluidized-bed heater and the air heater before they are sent to the baghouse.

In the baghouse, any flyash and attrited sorbent are removed as the exhaust gas moves on its way to the stack on the roof. The baghouse is provided with a nitrogen system. In the event of a high-temperature alarm (i.e., $550^{\circ} \mathrm{F}$ ), nitrogen is sent at 150 psig to deluge the baghouse. Flow is controlled by a solenoid valve and is limited to $\sim 100 \mathrm{scfm}$ by a restricting flow orifice. A hand valve bypassing the solenoid valve can also be used if necessary to provide fire control. The 150 psig nitrogen is also regulated to 125 psig or less and used for pulse cleaning of the filter bags.

Spent sorbent from the absorber, which can range from 700 to $900^{\circ} \mathrm{F}$ depending on the condition desired, is transported to the fluidized-bed heater. Here it is heated to the desired range of 800 to $1100^{\circ} \mathrm{F}$, using the flue gas and heated air from a natural-gas-fired heater before being discharged to the regenerator. The offgas from the sorbent heater is cooled by a water spray and passes through a baghouse to remove flyash and sorbent dust prior to being discharged to the atmosphere. The sorbent system plumbing has been designed so that the fluidized-bed heater can be eliminated by installation of spool pieces in place of the piping to the heater.

The sorbent flows in and out of the fluidized-bed heater (range between 0.65 to $3 \mathrm{lb} / \mathrm{min}$ depending on test conditions); the feed is controlled by a transport hopper between the absorber and the heater. The transport hopper has valves on the inlet and outlet that open and close on a timed sequence. Both can be closed, but both will not be open at the same time. From the absorber, the sorbent flows through a restricting orifice and fills the hopper through the open inlet valve, which closes when the hopper is full. An infrared level detector determines when the hopper is full. Instrument air pressurizes the hopper. The outlet valve then opens, transporting the sorbent to the heater; the outlet valve closes when the hopper is empty and the hopper pressure drops, indicating that the transport line is clear of sorbent.

The fluidized-bed heater contains approximately $1.9 \mathrm{ft}^{3}$ of sorbent, which is heated with 60 to $90 \mathrm{scfm}$ of heated air and flue gas from a natural gas-fired heater. The gas velocity through the fluidized-bed heater must be controlled to keep the sorbent fluidized; this is done by controlling the natural gas combustor (air heater) firing rate and the dilution air flow to the natural gas combustor. The gas distributor consists of a plate with 27 "J-tubes" that are 1/2-in in diameter and that direct air from the inlet air plenum, through the plate, and into the bed. The tubes are in the shape of an inverted letter $\mathrm{J}$ so that the outlets are directed back at the distributor plate about $3 / 4$ in from the plate. In this way, sorbent is prevented from going through the distributor plate when air is not flowing, and the 
air is evenly introduced across the bottom of the bed. The plate constitutes the bottom of the sorbent bed.

The fluidized-bed heater is designed for $1500^{\circ} \mathrm{F}$ shell temperature at 5 psig. The gas flow from the air heater is maintained to produce a fluidization velocity of 3 $\mathrm{ft} / \mathrm{sec}$, and temperature is limited to $1650^{\circ} \mathrm{F}$ by an interlock that shuts off the air heater burner fuel. The fluidized-bed heater inlet is lined with refractory for the higher temperature.

The fluidized-bed heater is designed for $5 \mathrm{psig}$ and has over-pressure protection set at 5 psig. There is no induced draft on the offgas. Normal operating pressure is a slight positive pressure from the air heater. The air blower maximum discharge pressure is $6 \mathrm{psig}$. With no induced draft, the pressure in the sorbent heater is positive in order to keep the sorbent fluidized. Whenever the air heater is operating, the pressure in the sorbent heater is positive; when the air heater is off, the sorbent system is shut down.

The fluidized-bed heater normally contains sufficient air for combustion if fuel is present. The regenerator vessel, which is isolated from the fluidized-bed sorbent heater by a lock hopper, uses natural gas as the regenerant. Sorbent is transferred from the fluidized-bed heater to the regenerator through a lock hopper, which has isolation valves on the inlet and outlet. Both valves can be closed, but both cannot be open at the same time. To transport sorbent once the inlet and outlet valves are closed, the inlet valve is opened on a timed sequence controlled by a personal computer system. When the valve starts to open, a slight nitrogen purge to the hopper is started to prevent air from the sorbent heater from entering the hopper. When the hopper's full-level indicator is activated, the inlet valve is closed. Once the inlet valve closed limit is satisfied, the outlet valve opens, and additional nitrogen flow to the hopper is initiated to gently blow gravity-flowing sorbent into the regenerator. Once the hopper's full-level indicator is deactivated, the outlet valve closes on a time delay to allow the hopper to empty. The nitrogen is shut off, and the cycle is restarted based on the timing established to maintain a constant sorbent flow. The nitrogen supply has a low pressure alarm; the sorbent system is shut down in the event of a nitrogen failure. The hopper provides isolation between the regenerator and fluidized-bed heater to prevent formation of an explosive mixture in the regenerator.

The hot gas that exits the top of the fluidized-bed heater may contain flyash from the transported sorbent and possibly some sorbent dust. The solids will be removed by a baghouse after the gas is cooled to below $500^{\circ} \mathrm{F}$ in a spray chamber (humidification cooler). The cooling is done with a dual-fluid nozzle using instrument air as the atomizing medium. The spraying of the water into the hot gas allows the water to evaporate and cool the gas. The air-heater burner fuel is turned off in the event of low air or low water pressure, or high temperature from 
the cooler into the baghouse. The cooler outlet temperature is regulated by controlling the water spray.

The air heater has a flame supervisory system designed to prevent explosions in the gas-fired fumace and flue gas downstream. This system has instrumentation to monitor the flame and shut off the fuel if air flow is low or fluctuates or if flame failure occurs. The system is purged upon startup and as a result of all flameouts. A forced draft blower can provide up to $175 \mathrm{scfm}$ air for combustion and for sorbent heating. The fluidized-bed heating medium consists of the flue gas from the air heater plus the air which is heated in the air heater burner.

The baghouse is designed for operation at $500^{\circ} \mathrm{F}$ and 30 -in WC; if the inlet temperature exceeds $550^{\circ} \mathrm{F}$, the air heater is shut down. The baghouse is open to the outside environment. The bags are pulsed with nitrogen for cleaning. Typically, particulate is dumped from the bottom into drums; these containers can be isolated from the baghouse by closing a valve. A nitrogen purge to the baghouse bottom is started in the event of high temperature in the baghouse.

\subsubsection{Regenerator}

The purpose of the regenerator is to maintain the heated, spent sorbent from the fluidized-bed heater in a reducing atmosphere of natural gas (or possibly hydrogen in the future) in order to convert the $\mathrm{CuSO}_{4}$ back to elemental copper on the sorbent. Gaseous $\mathrm{SO}_{2}, \mathrm{CO}_{2}$, and $\mathrm{H}_{2} \mathrm{O}$ are also formed. These gases, along with excess reducing gas, are routed through a condenser to remove the water vapor and then to the incinerator where excess reducing gas is burned off. The exhaust gases are then routed to the roof where they are diluted with large amounts of air by means of a dilution blower prior to being routed up the stack. Gas analyzers are used to measure the concentrations of $\mathrm{SO}_{2}, \mathrm{CO}_{2}, \mathrm{CH}_{4}$, and $\mathrm{O}_{2}$.

The regenerator is a vertical vessel with a sorbent inlet at the top and a sorbent outlet at the bottom. It is constructed of nominal 16-in diameter schedule 10 pipe, 316 stainless steel. It has a cone section welded to the bottom and a flanged top. The inside of the regenerator was ALONized -- a process that diffuses aluminum into the grain structure at the surface of the stainless steel, providing an effective corrosion barrier. Reducing gas and/or nitrogen purge gas are introduced at the bottom through a sparger. Flow of these gases is controlled by the PCS. A nonintrusive level detection system is incorporated and also reads out on the PCS. To minimize heat loss, electric skin heaters sectioned into four control zones are incorporated and are controlled from the PCS. The four zones are (1) bottom cone, (2) bottom cylinder, (3) middle cylinder, and (4) top cylinder. The regenerator vent stream is isolated from the incinerator by a pneumatically operated (fail-closed) ball valve that is operated manually from the PCS. 
The non-intrusive continuous level detector consists of three shielded radiation sources emitting collimated gamma rays. Each level gauging device uses cesium 137 as the source of radiation. The three radiation sources are located on one side of the regenerator, while the receivers (detectors) are located on the opposite side. One gauge contains 40 millicuries, and the other two each contain 20 millicuries. The energy received by the detector (i.e., not blocked by the sorbent) is inversely proportional to the sorbent height. The gamma radiation is emitted from each holder through a special shutter that is operated by a red lockable lever at the holder top. The gap between the source holders and the regenerator is shielded by the holder mounting brackets to eliminate any possible scatter. After these gauges were installed, a survey was conducted with the shutters first closed and then opened to determine the radiation exposure around the source housing, regenerator, and receivers. Additional shielding was not required and regulations pertaining to the operation and storage of these radiation devices have been followed.

Spent sorbent, which has been preheated in the fluidized-bed heater, is fed from the absorber into the top of the regenerator (sorbent flow range is 0.65 to 3 $\mathrm{lb} / \mathrm{min}$ ), where it is contacted by a reducing gas (natural gas) to remove the sulfurcontaining compounds from the sorbent. The offgas from the regenerator, containing reducing gas, $\mathrm{CO}_{2}, \mathrm{SO}_{2}$, and possibly other sulfur-containing gases, passes through an incinerator before being discharged to the ambient air above the roof of the building. The regenerated sorbent exits the bottom of the regenerator and flows to a cooler before being returned to the absorber.

The regenerator is designed to withstand $1500^{\circ} \mathrm{F}$ at $5 \mathrm{psig}$ and has a 5 psig rupture disc for overpressure protection. The regenerator normally has a slight positive pressure, approximately 10 -in WC, and occasionally has a slight negative pressure due to the induced draft blower on the downstream side of the incinerator. The source of pressure is the natural gas, which is measured and controlled. Nitrogen could be used as a diluent. Normally the regenerator offgas piping is open to the atmosphere through the incinerator. When the regenerator offgas piping is closed, the nitrogen and natural gas flows will be off. When the offgas is open to the incinerator, the induced draft can be controlled by the air flow to the incinerator and by the dilution air valve setting. The incinerator must be operating to open the regenerator offgas valve; this valve must be open to initiate any gas flow.

The dilution air blower is connected downstream of the incinerator and functions as an induced draft fan. Additionally, a dilution air valve is provided to bleed ambient air into the suction side of this fan. This is required for normal operation to keep the temperature of the fan within safe limits. Theoretically, the valve setting can be adjusted to change the amount of negative pressure maintained in the incinerator: close the valve to make the incinerator pressure more negative, open the valve to make it less negative. 
The sorbent regeneration is dependent upon temperature. To maintain a constant and uniform temperature in the sorbent bed, the regenerator shell has electric heaters. The heaters are arranged into four zones, each of which has independent temperature measurement and control; if the heaters exceed $1400^{\circ} \mathrm{F}$, they are automatically shut off. The shell temperature is measured and controlled by the heaters. The heaters on the regenerator are WATLOW FIREBAR units of specific lengths, voltages, and watt densities. The units are flat, about 1 -in wide, and mounted in contact with the vessel skin. All heating elements within a zone are wired in parallel so that operation is possible even if an element should burn out. The regenerator heating is divided into four separately powered and controlled zones: bottom outlet cone, bottom cylindrical section, middle cylindrical section, and top cylindrical section. The top zone is above the expected level of sorbent and is provided as a buffer against temperature loss from the zones below.

Natural gas at a flow up to $2.5 \mathrm{lb} / \mathrm{hr}$ is used for the reducing medium to regenerate the sorbent. This flow can only be started if the regenerator offgas contains less than $1.5 \%$ oxygen and the incinerator is operating. Nitrogen is introduced into the bottom of the regenerator and is used to purge air from the regenerator prior to initiation of reducing gas flow and to purge any remaining reducing gas from the regenerator during shutdowns. Nitrogen could also be used to dilute the reducing gas in the regenerator. The flow rate of nitrogen can also be measured and controlled.

The sorbent flow system has many engineering designs which isolate the regenerator from sources of air and thus prevent any explosive mixtures. The regenerator is isolated from the sorbent heater by a lock hopper that has solenoid operated valves on the inlet and outlet. Both valves have opened and closed limit switches which prevent them from being open at the same time. During the gravity-induced sorbent transfer from the heater to the regenerator, once the lock hopper outlet valve is closed, a timed cycle starts. To transfer sorbent, the following occurs. A small flow of nitrogen is started to the lock hopper when the inlet valve is opened. As sorbent from the heater fills the hopper, air is excluded by the nitrogen purge. Once the hopper is filled, a high level switch is activated that closes the inlet valve. Once the hopper inlet valve has closed as indicated by the limit switch, the hopper outlet valve opens, and additional nitrogen is initiated to convey the sorbent from the hopper into the regenerator. The outlet valve stays open for a timed period to allow time for the sorbent to empty, then the outlet valve closes. The cycle restarts when the signal to open the inlet valve is given, but the inlet cannot be opened unless the hopper's outlet-valve-closed limit switch has been satisfied. The regenerator-sorbent. outlet stream has a similar hopper arrangement to prevent any air from the fluidized-bed cooler from entering the regenerator.

Air is prevented from entering the regenerator from the incinerator by the direction 
of flow, which is from the regenerator to the incinerator. The regenerator offgas vent valve cannot be opened until the incinerator is in operation. Once the incinerator is in operation and the induced draft blower is operating, all flow is from the regenerator to the incinerator.

The regenerator has been pressure tested and is leak checked as a normal part of each startup. This identifies any leaks as well as any plumbing that may have been left open and verifies that the rupture disc is intact. The regenerator pressure is close to ambient; if any leaks do occur during operation, they tend to be very minor.

If the regenerator rupture disc releases, the pipe would be open to the surroundings, which could result in entry of air. The rupture disc has a proximity switch, which is activated if the rupture disc is exposed to the set pressure. In that event, the natural gas flow is automatically shut off, the sorbent flow is stopped, and a nitrogen purge is started at the bottom of the regenerator.

As an additional measure to prevent the formation of explosive mixtures, the regenerator offgas is continuously analyzed. If the regenerator offgas exceeds $3 \%$ $\mathrm{O}_{2}$, a solenoid operated valve on the nitrogen automatically flows nitrogen to the regenerator bottom and another solenoid valve shuts off the natural gas. In addition, the sorbent flow is stopped. Two paramagnetic oxygen analyzers are used: one is located locally at the regenerator and has a response time of approximately 45 seconds, and the other is located in the analyzer room. The analyzers are calibrated before and periodically during each test. Both analyzers cannot be taken out of service at the same time. The minimum oxygen concentration that will support a natural gas flame is $12 \%$; the natural gas shut off is set at $3 \%$.

\subsubsection{Incinerator}

The purpose of the incinerator is to burn any excess reducing gas that may be present in the regenerator vent stream. If elemental sulfur and/or hydrogen sulfide also are produced in the regenerator, the incinerator would thermally convert these constituents to sulfur dioxide.

The offgas from the regenerator, less than $3 \mathrm{scfm}$, contains a high concentration of $\mathrm{SO}_{2}$, possibly other sulfur-containing compounds, and some unreacted reducing agent (natural gas). The stream is cooled in an ice bath to eliminate moisture, monitored for flow rate, analyzed, and then sent to the incinerator combustion chamber. Any remaining reducing agent is consumed, and any sulfur compounds that may exist are oxidized to $\mathrm{SO}_{2}$.

The incinerator is a natural gas-fired burner with a capacity of $1,000,000 \mathrm{BTU} / \mathrm{hr}$. 
Its heated chamber is 14.125 -in in internal diameter by $4 \mathrm{ft}$ long. A blower with $500 \mathrm{scfm}$ capacity provides both combustion air and cooling air that dilutes the regenerator offgas. A blower on the exiting flue gas provides an induced draft and additional dilution. The induced draft blower is designed for $300^{\circ} \mathrm{F}$. To prevent damage due to high inlet temperatures, it has a high temperature incinerator shutoff set for $300^{\circ} \mathrm{F}$.

The incinerator has a flame supervisory system located on an I/O panel at the 30foot level. It is designed to prevent explosions in a natural gas-fired burner system. The unit controls burner interlocks and governs ignition sequence. A burner flame status is input to the process control system, and a remote burner enable/disable is output from the process control system. The system includes shutoff of fuel in the event of any furnace flameouts, fluctuations in fuel feed, or loss of combustion air. Purging is also required during startup and as a result of any flame failures. Also, the regenerator offgas has a control valve located between the incinerator and the regenerator. The valve cannot be opened unless the incinerator flame has been confirmed, and it closes in the event of any flame failures.

\subsubsection{Fuidized-Bed Cooler}

The purpose of the fluidized-bed cooler is to adjust the temperature of the sorbent to that required by the absorber. The term is actually a misnomer because the sorbent sometimes requires heating.

The system consists of a Spencer blower mounted on the roof, an electric air heater, and the fluidized-bed cooler. Air from the Spencer blower is heated by an electric heater and used to fluidize the sorbent and adjust its temperature. The electric heater warms the air prior to its entry into the fluidized-bed cooler, since ambient temperature air would overcool the sorbent. Sorbent cannot be transferred through the bed until it has reached a temperature of $\sim 150^{\circ} \mathrm{F}$. Therefore, the fluidized-bed cooler will be warmed to at least $150^{\circ} \mathrm{F}$ prior to the startup of the transport system.

The fluidized-bed cooler is a vertical vessel with three basic sections. Hot air from the electric heater comes into the bottom inlet plenum and then passes into the middle fluidized-bed section through " $\mathrm{J}$ " tubes mounted in a distributor plate that separates the two sections. The evenly distributed air promotes good sorbent fluidization and heat transfer. The vessel expands to a larger cross-section above the bed, slowing the air velocity and allowing the sorbent particles to stay behind. Air exiting the top of the disengagement zone is routed to the stack.

Sorbent flows from the regenerator into a nitrogen-purged lock hopper then through a downcomer leg in the side of the fluidized-bed cooler, where it is cooled 
with air and is retumed to the absorber. The fluidized-bed cooler is isolated from the absorber by an air-purged lock hopper. The cooling air medium can be heated by an electric heater, depending on the test conditions desired.

The fluidized-bed cooler has been designed for operation at $1000^{\circ} \mathrm{F}$ and $5 \mathrm{psig}$. It is constructed of 14-in and 10-in schedule 10, type 304 stainless steel pipe, with a flanged bottom and flanged top. The cooling air is supplied by a Spencer blower with a capacity of $170 \mathrm{cfm}$ at 70 -in WC. The sorbent cooler is open to the atmosphere. The cooling air temperature is controlled, and the heater has a high outlet temperature shutdown. The sorbent also has a high temperature heater shutoff set for $990^{\circ} \mathrm{F}$. The inlet air flanged spool piece has been lined with refractory. The air heater temperature is controlled to a maximum of $1100^{\circ} \mathrm{F}$.

Fluidization within the vessel is provided by the J-tube design. The fluidized-bed cooler distributor is identical to the fluidized-bed heater distributor (Section 5.2.2), except that it has 18 instead of $27 \mathrm{~J}$-tubes. It also has a drain hole in the middle of the plate which is presently being used as a vessel emptying drain.

The cooling air flow is controlled to maintain a specified fluidization velocity through the cooler. Mass flow, bed temperature, bed dimensions, and an assumed bed pressure drop are all considered. Air from the sorbent cooler is vented to atmosphere above the roof after going through a cyclone separator. The sorbent cooler has a sight port, which is currently out of service. The air heater also has a low flow switch so that it cannot be energized without a minimum flow of air through the heater.

\subsubsection{Sorbent Piping/Lock Hoppers}

The purpose of the sorbent transport system is to transfer sorbent from vessel to vessel in the sorbent loop at a specified rate. It must do this without allowing oxygen to enter the regenerator and with a minimum of gas transfer into or out of both the regenerator and absorber. Sorbent is added to the system through the fluidized-bed cooler using a small manually operated lock hopper. The need for more sorbent is determined by observing any changes in the pressure drop across the fluidized-bed heater and fluidized-bed cooler. A constant level in the absorber is always maintained. Operators must assure that the level in the regenerator remains constant.

The sorbent transfer system consists of a regenerator inlet lock hopper, regenerator outlet lock hopper, absorber inlet supply hopper, and absorber outlet transport hopper. Sorbent flows are balanced during a test by maintaining a constant flow rate from each hopper. Nipples, to which are attached fiber-optic infrared sources and receiver cables, are located on the hoppers to detect the various levels to which sorbent is permitted to rise. Nominal transport volumes and weights (at 35 
lb per $\mathrm{ft}^{3}$ ) are:

$\begin{array}{lll} & \frac{\text { Volume }}{\text { Low level }} & \text { Weight } \\ \text { Medium level } & .030 \mathrm{ft}^{3}, & 1.05 \mathrm{lb} . \\ \text { High level } & .057 \mathrm{ft}^{3} & 2.00 \mathrm{lb} . \\ .086 \mathrm{ft}^{3} & 3.00 \mathrm{lb} .\end{array}$

Nitrogen is used in the regenerator sorbent inlet and outlet lock hoppers to facilitate sorbent flow and to act as a purge to prevent any oxygen from the atmospheres in either the fluidized-bed heater or fluidized-bed cooler from entering the regenerator. The nitrogen is received from the header at $150 \mathrm{psig}$ and is regulated to 15 psig with pressure safety valve protection to 20 psig prior to being distributed to its destinations. Metering valves control the flow rate of nitrogen into the inlet lock hopper and outlet lock hopper during the entire transport cycle. Valves also control the flow rate of additional nitrogen from the time the sorbent inlet valve begins to close to the time the sorbent outlet valve begins to close. These valves are set to permit minimum nitrogen flow while promoting good sorbent flow and assuring that no oxygen enters the regenerator.

Instrument air is used in the absorber inlet supply hopper to assist in the gravity flow of sorbent from the hopper to the absorber. It is also used in the absorber outlet transport hopper to pneumatically lift sorbent from the absorber outlet at ground level to the fluidized-bed heater at the top level, $\sim 38$ feet above. Instrument air comes from the supply header at a pressure of $\sim 100 \mathrm{psig}$ and is regulated to 30 psig and pressure safety valve protected at 35 psig. It is then split into two branches to go to the absorber sorbent transport and inlet supply hoppers. Each of these branches has a pressure regulator to control the air for each use.

The desired rate of sorbent flow is accomplished by two things: (1) the volume of sorbent in the hoppers in each transport load (as indicated by the level switches) combined with (2) the amount of time elapsed between loads. For the regenerator inlet and outlet hoppers and the absorber outlet transport hopper, the amount of sorbent per load can be varied by installing the infra-red level sensors in the appropriate ports provided at either the $\sim 1, \sim 2$ or $\sim 3 \mathrm{lb}$ levels. The level for all three of these hoppers must be the same. The level in the absorber inlet supply hopper is fixed at $\sim 3 \mathrm{lb}$. (The transport hopper is currently filled on a timed basis only.)

The beginning of the transport cycle for the regenerator inlet and outlet and the absorber outlet is initiated by the PCS on a timed basis. The time cycles can be varied from 60 to 300 seconds. The absorber inlet transport cycle begins every time the sorbent level in the top of the absorber drops below the level switch.

In general, a transport cycle consists of the following steps: the inlet valve opens, 
sorbent flows into the hopper, the level switch sends a signal to close the inlet valve, the outlet valve opens until the level switch clears and a short amount of time elapses, and then the outlet valve closes. Nitrogen or air flows into the various hoppers during the cycle.

The transport system operates in one of three modes:

Automatic: This is the normal mode of operation. When this mode is initiated, the hoppers cycle according to the cycle interval set by the operator.

Semi-aurtomatic: This mode is used to transfer sorbent between selected vessels to restore the proper inventory to each vessel. This is necessary because it is impossible to transport the exact same amount of sorbent per cycle with each of the hoppers and so over time the inventories become imbalanced. Also, some sorbent is lost from the system.

Mamual: This mode is used only for trouble-shooting and normal maintenance of the transport system. It allows selection of a fill and an empty operation for each hopper. It supports fill cycle purging, empty cycle with pressurization, and interlocking between cycle operations. However, the level switches do not cause the inlet valves to close. Therefore, the hoppers can overfill in this mode.

The sorbent piping connects all the vessels in the sorbent flow system; this includes the absorber, fluidized-bed heater, regenerator, fluidized-bed cooler, and the hoppers that provide sorbent flow control and isolation between the vessels. The sorbent circulates continuously through the closed plumbing system in the range of 0.65 and $3 \mathrm{lb} / \mathrm{min}$. The flow rate is controlled by the timing of the operation of the transport and lock hoppers and by the level indications in the vessels and hoppers.

The piping is 3/4-in outer diameter by 0.049 -in thick stainless steel tubing and 1$1 / 2$ in schedule 40 stainless steel pipe that has welded flanged ends for connection to hoppers and vessels. The piping is designed for at least $1000^{\circ} \mathrm{F}$ and $30 \mathrm{psig}$, and it can withstand $1500^{\circ} \mathrm{F}$ at the fluidized-bed heater outlet and regenerator inlet. It will operate up to $1000^{\circ} \mathrm{F}$ and normally less than $5 \mathrm{psig}$ as each vessel in the system is open to the atmosphere, except for the lock hoppers. Plugging of the sorbent in the piping could result in higher pressures within the piping from the medium used for sorbent transport, air or nitrogen. All piping has been pressure tested and leak checked. The three gravity-fed links have expansion joints. The sorbent plumbing system consists of a large loop, approximately 40 feet from top to bottom and 20 feet wide.

The inside walls of the piping were inspected and cleaned to provide a smooth surface to prevent plugging of sorbent flow; the inside walls of all welds were 
ground smooth. Plugging of sorbent within the piping may still occur. During the shakedown testing, the sorbent piping was flow tested to identify bottlenecks and potential plugs and to verify and fine tune the sorbent flow rate. The sorbent is sifted to remove fines prior to the initial charging and will have some attrition during operation. Attrition in the various components of the transport system have been characterized, and results can be found in Appendix C.

The sorbent fluidized-bed heater and the fluidized-bed cooler can both be bypassed by making physical changes to the system piping arrangement. These changes can be made dependent upon the sorbent and the ensuing test parameters required. There are currently no plans to bypass either vessel.

\subsection{Instrumentation and Controls}

The LCTS consists of two basic operating systems: generation of flue gas using a coalfired furnace and operation of a sorbent flow loop that removes $\mathrm{NO}_{x}$ and $\mathrm{SO}_{2}$ from the flue gas and then regenerates the sorbent for reuse. The flue gas generation system is controlled using a Gateway $20004 \mathrm{DX}-33 \mathrm{~V}$ personal computer (PC) which has process control and data acquisition functions; this PC is located in the control room in a highbay. The operation control software (GENESIS by Iconics) is linked to the process hardware through input/output system modules located throughout the facility. The sorbent flow system is monitored and controlled using an ULTRA PC.

The process control software and process valves are designed to be failsafe. Design features include the following: spring-return pneumatically actuated valves, current-driven input and output devices, double block-and-bleed isolation systems, overpressure protection devices, self-checking flame detectors, failsafe logic wiring, a hard-wired emergency stop system, etc. The installation conforms to ISA, NFPA, NEMA, and NEC codes and standards.

An uninterruptable power supply (UPS) provides electrical power backup for the PCs, video monitor, and printer. The UPS is located in the control room and uses continuously charged batteries. It conditions the incoming power supply for the PCs to provide surge protection, dampen power fluctuations, and provide sufficient power to operate the PCs during a power failure. This backup is insufficient to permit LCTS operation.

The process and all parameters are displayed on a color monitor at various levels of detail, which the operator can select. Graphic selection, set-point entry, and all other process control functions are performed using a mouse or keyboard. In addition to the graphic display, the operating software provides real-time trending, data acquisition and historical trending, alarm management and response, on-line help to operators, and a file utility. Access to various levels of software use and modification are controlled by password. Data are stored on the PC hard disk. The data can be viewed or printed while the control system is on line. 
Alarms and operator events are graphically displayed as well as recorded on a printer. The system alarm summary documents all alarms on a first-out basis. Alarms indicate that a given parameter is out of the expected range (set range).

All combustion systems have been designed with flame supervisory control systems designed to comply with the NFPA standards for the prevention of explosions in natural gas and coal-fired equipment. This includes the use of flame detectors to shut off all fuels as a result of fluctuations in fuel flow, low combustion air, failure of igniters or flames, and any process conditions that require the system to be shut down.

Extensive functional testing of all process control logic was conducted during shakedown. This required a systematic functional check of all instrumentation, process controls, alarms, interlocks, valve operators, and all data acquisition to verify that all were installed properly, performed the function intended, had proper set points and alarms, had correct fail safe position, and generally worked properiy. During the shakedown and debugging of the process control logic, the operating personnel also verified that all instrumentation labels and identification were consistent with the graphics, data acquisition and controls, P\&IDs, standard operating procedures, and identification in the field.

Isolation valves on the inlet and outlet of the regenerator prevent explosive mixtures from forming. These valves have limit switches to provide feedback of the full opened or full closed position of the valves. All lock hoppers are designed so that the inlet and outlet valves cannot be open at the same time. The regenerator lock hoppers have limit switches to prevent both valves from being open at the same time.

The system has an emergency shutdown that can be activated from the PC or from locations in the field at various levels of the platform. Once activated, the process is quickly shut down in a safe condition, which involves shutoff of all fuel, regeneration reducing gas, and spiking gases. Some of the other processes are shut down due to subsequent interlocks. This emergency stop system is independent of the process control program as it is hard wired.

The functional process control of the furnace operation and the sorbent flow system are detailed in functional control specifications for both systems.

\subsection{Electrical Distribution System and Motor Control Center}

Electrical power for the LCTS is supplied from a substation located approximately 60 feet from the building. The substation has a $1000 \mathrm{KVA}$ transformer that operates on 2300 VAC and provides the 480/277 VAC for the highbay. The feed conductors from the substation enter the building through an underground bank of four set in PVC conduit that terminates in the electrical utility room. The power switchboards and motor control center are located in this room. The main service disconnect is equipped with a micrologic electronic circuit breaker and has a 2000 amp rating. It is adjustable and has settings for 
long-time and short-time pickup and delay and has instantaneous trip and ground fault protection. The ground fault setting is adjusted to 1200 amperes with a maximum time delay of one second.

A 600 amp switchboard in the utility room provides all 480 VAC power for the LCTS, including power to the motor control center. The switchboard is rated for $600 \mathrm{amp}$ and $600 \mathrm{VAC}$ and is grounded to the building ground system.

All motor starters are full voltage and nonreversing. They are equipped with magneticguard motor circuit protectors for overcurrent protection and melting alloy overload relays for overload protection. Electrical tests to measure insulation and grounding were conducted for all branch circuit wiring, as well as for motors and disconnects. All equipment exceeded the 1 megohm minimum. The building lightning and ground grid were tested and found to be adequate.

Electrical distribution panels and a transformer in the highbay provide 208/120 VAC for use by the LCTS at the test stand and for the control room and analyzer room. The electrical equipment has been grounded to the building ground system.

Electrical power for the vessel electrical heaters is supplied from an enclosure; two separate sources of power are supplied to this enclosure: 480 VAC and 208/120 VAC. Both are terminated on power blocks and equipped with arcing ground-fault protection. The ground-fault protection will operate a shunt, which opens to trip the breaker to disconnect the heater power in the event of a ground fault that exceeds one ampere. Each heater power supply is fused for overcurrent protection, and each has contacts wired to high-temperature interlocks to deenergize the heaters as a result of high temperatures.

Most of the blower motors can be started only from the control room; however, each has a disconnect located at the motor, which can be used to deenergize the motor and stop it in the event of an emergency. The captive cooling water pump has a local start/stop station. The incinerator dilution air and combustion air blowers operate as a locally controlled unit; only permissives and interlock control are provided at the control room process control logic.

The electrical equipment is designed for general purpose indoor use, except for the roof applications. The LCTS complies with the requirements of the NEC. All disconnects and equipment located on the roof are designed to be weather proof, NEMA 4X. The disconnects include means to connect safety interlocks for the associated motors.

\subsection{Compressed Gases in Cylinders}

Four rooms adjacent to the highbay are designed for housing the following cylinders of compressed gas: (1) flammable and combustible materials; (2) poisons/hazardous materials such as $\mathrm{SO}_{2}$, NO, and ammonia; (3) oxidizers; and (4) cylinders of calibration gases that 
contain mostly inert gas. These cylinders are segregated by DOT hazard class.

Each room is separated from the other and from the highbay by fire-rated walls constructed of cement block. Each room has forced ventilation provided by exhaust blowers located on its roof. The access door to each room has a louvered section for fresh air makeup. Each room has fire protection provided by a sprinkler system, means to secure cylinders, and means to provide grounding. Three of the rooms have heat available.

Each room has continuous ventilation whenever cylinders are in place, especially the rooms that are used for flammable gases and for toxic materials. The blowers have one speed for continuous air flow. The ventilation rate is a nominal 4 to 6 changes per hour. The two rooms that contain the flammable materials and calibration gases are equipped with explosion vents in the ceiling; these can be manually activated.

Gas detectors with alarms for $\mathrm{SO}_{2}, \mathrm{NO}$, and $\mathrm{NH}_{3}$ have been installed in the room containing hazardous materials to wam personnel prior to their entry into the room if a release has occurred. The room containing flammable gases has continuous forced ventilation, so that if a leak does occur, flammable gas will not accumulate and an explosive mixture will not result. A combustible gas detector with an alarm has been installed in this room. Cylinders of calibration gas that contain over $1 \%$ of a poisonous material also are stored/used in the hazardous-gas cylinder room. The calibration gas room contains only cylinders which are primarily inert gas; all contain less than $1 \%$ of any hazardous constituents.

All cylinders are identified as to contents. Each supply has a pressure regulator and a means to vent, purge, and depressurize the plumbing prior to opening or changing cylinders. Each supply has a pressure relief valve that is plumbed to discharge outside above the roof. Cylinders of toxic or flammable gas have excess-flow check valves to physically limit the maximum flow from the cylinders.

\subsection{Gas Analysis}

Gas analysis for data acquisition is an integral part of the LCTS operation. During operation, one instrument technician is dedicated to calibration and maintenance of the gas analysis sample streams and analyzers. All analyzers are calibrated and verified to be properly working prior to each test and recalibrated routinely during each test.

Most of the gas analyses are part of the data acquisition required to determine whether the dry, regenerable process being tested is functioning as designed and to evaluate performance of the sorbent. Combustion flue gases are analyzed to assess and control burner operation. The regenerator offgas oxygen concentration is analyzed by two analyzers to prevent explosive mixtures from being formed in the regenerator. 
The sample streams all require use of a pump to draw a sample because the system pressure is near ambient or a slight negative pressure. All sample streams have a nitrogen supply, which can be used for zeroing analyzers and purging sample streams of hazardous contaminants. The nitrogen from the header is at $150 \mathrm{psig}$, but the pressure is reduced to 5 to $10 \mathrm{psig}$ and pressure protection is used.

The operating system contains gases that are at temperatures from 700 to $1000^{\circ} \mathrm{F}$. These must be cooled, water vapor must be removed, and dust must be removed prior to analysis to avoid damage to analyzers or plugging of the sample streams. Each stream has dust filters as necessary, and either ice baths to cool and remove water or Perma Pure assemblies to dry the sample gas.

Each sample stream has flow, temperature, and pressure measurement and a five-way valve for zeroing, calibration, and sampling. A mid-point gas also is used during calibration to assure the linearity of the analyzers. Cylinders of calibration gases are maintained in the cylinder rooms.

The flue gas is continuously sampled before and after the reactor and at other LCTS locations. (See Appendix A.) Single-stage vacuum pumps with extended heads transport the sampled flue gas through 0.25 -in-diameter stainless steel lines, maintained at about $300^{\circ} \mathrm{F}$, to either an ice bath and/or a permeation dryer. A dual system was designed to minimize the amount of sampled flue gas that the Perma Pure dryer needs to condition. The ice traps remove water from the sampled flue gas that feeds the following:

- Paramagnetic $\mathrm{O}_{2}$ analyzers (Rosemount 755R and Beckman 755 and 755A), which are used for air in-leakage determination.

- Rosemount 870 infrared $\mathrm{CO}_{2}$ analyzers.

- Rosemount 880A CO analyzer.

- Beckman $864 \mathrm{CH}_{4}$ analyzer.

Perma Pure dryers are used to remove water from the sampled flue gas that supplies:

- Rosemount 880A and Horiba VIA-500 infrared $\mathrm{SO}_{2}$ analyzers.

- Thermoelectron Model 10 chemiluminescent $\mathrm{NO}_{x}$ analyzers.

The inlet of each Perma Pure dryer (Model No. PD 750-24SS) is located in a heated enclosure to eliminate condensation. Although the flue gas enters the Perma Pure dryer at $300^{\circ} \mathrm{F}$, the purge nitrogen enters countercurrently at room temperature and at lower pressure. A second Perma Pure dryer is used in series on the absorber inlet and outlet sample lines to further reduce the dew point.

\section{$5.7 \quad$ Utilities}

\subsubsection{City Water}

City water from the site header is used for safety showers and eye wash stations, 
cooling water atomized and sprayed into the two humidification coolers, and makeup water for the LCTS captive cooling water system. All users are isolated from the site city water header by a backflow preventer.

The water header is normally $85^{\circ}$ to $100 \mathrm{psig}$; the pressure within the two humidification coolers is near atmospheric pressure or slightly negative. The supplies to both coolers have check valves to prevent instrument air from entering the water piping in the event of spray nozzles plugging.

The water supply for the captive cooling water system has a pressure regulator and a check valve to prevent back flow from the captive water system. The city water supply header has the backflow preventer. City water is used to fill the system and for periodic water makeup.

A 25-gallon tank is part of the humidification system and can supply water for a limited time. However, loss of city water for an extended time will result in a shutdown of the LCTS as a result of high temperatures in the flue gas to the baghouse and in the heated air from the sorbent heater. The water supply has no automatic system shutdown.

\subsubsection{Captive Cooling Water}

The coal-fired furnace and flue gas piping from the furnace have their own captive cooling water system. The captive water system is filled with city water and treated with corrosion inhibitors. The water is circulated through a closed piping system by a pump with a capacity of $160 \mathrm{gpm}$ at $100 \mathrm{psig}$ and a maximum discharge capacity of 120 psig. The water flows through six sets of panel coils on the furnace shell, through the jacket of the flue gas heat exchanger (cooler), and through cooling coils on the flue gas piping and furnace penetrations.

Each panel coil circuit has water flow and temperature measurement; water flow is controlled by manually setting a valve on the return from each coil. The flue gas temperature from the furnace is measured and has a furnace shutdown for high temperature.

The water supply to the flue-gas heat-exchanger cooler jacket is controlled. The return has flow and temperature measurement, a high temperature alarm, and furnace shutdown if the water flow is less than $5 \mathrm{gpm}$. The furnace will also be shut down as a result of low cooling-water supply pressure from the pump. Although available, the flue gas heat exchanger (cooler) is currently not in use. The water system is pressurized to 21 psig to allow slight superheating of the water. An expansion tank on the pump suction allows for expansion and contraction. An air separator has been installed at the high point of the system to allow filling and removal of air from the water. The cooling water supply piping 
has a pressure relief valve set for $150 \mathrm{psig}$, and the return header has a pressure relief valve set for $125 \mathrm{psig}$. The water temperature will be controlled at less than $200^{\circ} \mathrm{F}$ from the water cooling circuits. The captive cooling water will be cooled to approximately $140^{\circ} \mathrm{F}$ before returning to the circulating pump by water from the cooling tower using two shell and tube heat exchangers.

The city water supply to the LCTS has a "Y" type strainer which will remove some particulates. The captive water will be treated to prevent corrosion. The captive water system may become fouled with scale or corrosion and periodically require cleaning; this will be indicated by higher cooling-water return temperatures and low water flow.

\section{7 .3 Nitrogen}

Nitrogen will be used for the following: (1) transporting coal from the preparation area to the coal silo, (2) inerting the coal feed silo, (3) purging lock hoppers, (4) purging and calibrating sample gas streams and analyzers, (5) purging the regenerator and possibly diluting the reducing gas, (6) pulsing bags in baghouses for flue gas, sorbent fluidized-bed heater, and coal silo, (7) pulsing the absorber sorbent screens, (8) purging compressed gas cylinder plumbing, and (9) purging vent headers to exclude air.

To prevent air from entering the regenerator and to prevent natural gas from entering the fluidized-bed heater, the lock hoppers isolating these vessels are purged with nitrogen during sorbent transfer. The flow is controlled by metering valves; the pressure is controlled by regulators. The hoppers are protected from overpressurization by a relief valve set at 20 psig.

Nitrogen is used in the regenerator for purge prior to initiating reducing gas during startup and for purge during shutdown of the system. The nitrogen can also be used to dilute the reducing gas during sorbent regeneration. The regenerator rupture-disc vent header is purged to exclude air from the header. Nitrogen is used to purge the $\mathrm{SO}_{2}, \mathrm{NO}$, and $\mathrm{NH}_{3}$ plumbing before changing cylinders. It is also used to zero gas analyzers when calibrating and to purge sample streams prior to opening.

The baghouses and the absorber sorbent screens are pulsed using nitrogen. (The option exists to pulse the absorber screens with compressed air.) Each supply has pressure regulation, and each baghouse is open to the atmosphere.

The coal feed silo is inerted prior to filling with coal and afterwards is maintained under a nitrogen blanket supplied by continuous nitrogen purges to the bottom.

Nitrogen is supplied at ambient temperature by the site 150 psig header and is pressure regulated as necessary for each use. The nitrogen piping in the building 
has been pressure tested and leak checked. The nitrogen plumbing has no interconnections with the instrument air or other utility headers and is isolated from all users by check valves. The LCTS is not operated unless nitrogen is available; the supply header has a low pressure interlock to alert the operators.

\subsubsection{Compressed Air}

The LCTS cannot be operated without instrument air. Site instrument air is used for control-valve operation, solenoid-valve operation, coal transport from the coal feeder to the furnace, sorbent transport from the absorber to the fluidized-bed heater, purging of a sorbent lock hopper, atomization of water sprays in two coolers, and purging of the sightglass port on the fluidized-bed cooler.

The site header operates at approximately $100 \mathrm{psig}$; the instrument air supply is limited. The header in the highbay has a low-pressure alarm and interlock, which will shut down the system as a result of low air pressure. The air header has no backup from another source and no interconnecting piping with the nitrogen system.

After being compressed, the air is typically dried to a dew point of approximately $-50^{\circ} \mathrm{F}$. If the driers are overloaded, the instrument air header could contain moisture. Not all compressed air users at the LCTS require dry air, but the air should be dry for sorbent transport and all instrumentation. The air system within the highbay has no means to dry air.

Not all uses at the LCTS are rated for operation at full header pressure. The instrument air use is detailed on process and instrumentation drawings. Each use that is not rated for full service pressure has pressure protection. Most instrumentation/valve operators are intermittent users of small quantities of air, but the combustor coal transport uses a continuous flow of $18 \mathrm{lb} / \mathrm{hr}$. The absorber inlet supply hopper can have an air purge (although it is currently inactive). The transport hopper uses approximately 3 to $5 \mathrm{scf}$ of air per cycle for sorbent transfer of a nominal 2-lb load.

\subsubsection{Natural Gas}

Natural gas is used as the reducing agent in the regenerator and for pilot gas and combustion gas in the furnace, the incinerator, and the air heater on the fluidizedbed heater. Natural gas is supplied from the site natural gas header. This header is controlled at $15 \mathrm{psig}$ and has redundant pressure control and pressure protection. The piping is all schedule 40 carbon steel. A volumetric analysis of the gas by gas chromatography yielded the following constituents: 


$\begin{array}{lrr}\text { Constituent } & & \text { Volume Per } \\ & & 0.09 \\ \text { Hydrogen } & & 0.89 \\ \text { Nitrogen } & & 90.18 \\ \text { Methane } & & 0.26 \\ \text { Carbon dioxide } & & 7.98 \\ \text { Ethane } & & 0.60 \\ \text { Propane } & & \end{array}$

The natural gas header was pressure tested and leak checked and purged with nitrogen prior to being placed in service. The flow to each user is measured and controlled, and the maximum flow is limited by a restricting flow orifice installed in the piping. Each supply has a positive means of isolation from the user provided by automatically actuated dual shutoff valves that typically have a vent between them. Each user has manually operated valves which can be closed when the system is shut down.

The three combustors all have pressure control and automatic high and low pressure shutoff of the fuel to prevent potentially explosive mixtures within the combustion systems. The natural gas flow to each burner cannot be started unless the igniter has been energized or the pilot flame has been confirmed, and the system has been purged. The natural gas is shut off to each burner in the event of flameouts or activation of the system interlocks.

The supply to the regenerator has flow and pressure measurement and flow control; two solenoid actuated shutoff valves and a manually operated valve are provided for isolation. This flow will be shut off as a result of oxygen detection in the regenerator and when the regenerator vent is closed. 
Before and during the initial shakedown, several areas for QA/QC implementation were delineated to assure that the data is accurate. Although most of the data is recorded and saved by a personal computer program (see Appendix A), certain hand data is recorded on a known frequency. This not only backs up the computer data in the event of a computer malfunction, but also produces a check with the computer processing during normal operation.

Logbooks are kept that detail planned and unplanned events that occur before, during, and after a test. Date and time of the event are also recorded. Examples of information that is recorded are the amount of sorbent added to the unit before and during a test; the date and time that the analyzers were calibrated; power outages; maintenance of instrumentation; modifications to the unit between tests; etc.

Some of the most important information is derived from the gas analyzer results. The voltages have been linearized. To guarantee that the linearity of each analyzer has not drifted, three points are chosen for calibration: a nitrogen for zero determination and two calibration gas mixtures. Calibrations are performed during each shift to eliminate any drift effects. These calibration sheets are archived. The analyzer information stored by the computer is periodically compared with the real time analog of the instrument to determine if any differences exist between the instrument and the recording device.

The bank of analyzers on the exit stream from the regenerator are periodically checked by obtaining a volumetric gas sample and analyzing it by gas chromatography. The sample is taken when the LCTS is at steady state at a set of process parameters. Comparisons of the $\mathrm{SO}_{2}, \mathrm{CH}_{4}$, and $\mathrm{CO}_{2}$ concentrations are made. 
Shakedown of the LCTS was begun in February 1995. A primary goal was to complete training of the operating personnel at the same time that all system equipment was functionally tested and ready for operational tests. The shakedown of the system was successful. The majority of the test objectives were met. Operation training was effective. Few computer problems occurred, and the control system performed well.

\subsection{Training}

The current test schedule requires continuous 24-hour operation for up to two weeks at a time. Three trained technicians per shift are required if coal is burned; two technicians per shift are required if natural gas is burned in the furnace. An instrument technician also is needed per shift. The training included a detailed review of the process flow diagram and all process and instrumentation drawings (see Appendix B), identification and functional testing of all components and subsystems, classroom review of standard operating procedures (SOPs) and emergency procedures, discussion of limitations of the equipment, reviews of all safety and health hazards and their controls and precautions [5], and shakedown operation of the system.

An SOP details the operation of the system so that the tests are repeatable and results are reproducible. The SOP provides sufficient information to the operating personnel for preparing the facility to operate, starting it, conducting normal operations, and shutting it down. The SOP contains only those steps which must be repeated for every operation.

Two SOPs were written for the LCTS: one for the flue gas generation process [6] and the other for the absorption/regeneration process [7]. Revisions were made during shakedown and initial operation. To ensure that they accurately reflect the system operation and that required procedures are being followed, the SOPs are periodically reviewed. Revisions are subjected to the same review and approval as the original procedures. Operating personnel are periodically reinstructed in the system operation using the SOPs.

An emergency shutdown procedure has been posted at the control room. In the event of a system emergency which requires a quick shutdown or if the building must be evacuated, personnel have been instructed to initiate the emergency shutdown.

Prior to each test, a test plan is prepared by DOE which details the test parameters. The specifications are reviewed with the operating personnel, and it must be verified that the system can be operated within the requirements of the SOP and the limitations of the system.

\subsection{Equipment Functional Testing}

The following are the results of the two periods of shakedown testing: 


\subsubsection{Coal Pulverizer}

A Pittsburgh Seam Coal was chosen for use in this period of shakedown of the LCTS. The coal was successfully pulverized (in shakedown period \#1) to a size of approximately $70 \%$ through 200 mesh. The coal was pneumatically transported to the highbay with little difficulty. The coal was stored in a silo that supplies the coal screw feeder.

\subsubsection{Coal Screw Feeder}

The screw feeder gave a fairly stable flow of coal to the furnace. The eductor would sometimes plug with scale. The source of this scale was thought to be residual scale from the pulverizer system, which had not been operated for several years. The first course of remedial action was to install a 10-mesh screen between the screw exit and the feed eductor. A pneumatic vibrator was attached to the screen to aid the sieving action. The coarse material was periodically removed by hand. However, this method was abandoned and a scalping screen was installed at the coal silo entrance. Use of the new system has eliminated the pluggage from any residual debris.

\subsubsection{Fumace}

The furnace was co-fired on natural gas and coal. Based on the maximum recommended rating for furnace operation, peak firing conditions obtained were $38 \mathrm{lb} / \mathrm{hr}$ coal with $4 \mathrm{lb} / \mathrm{hr}$ natural gas and $25 \%$ excess air. This corresponds to a thermal input of $680,000 \mathrm{Btu} / \mathrm{hr}$ and yields approximately $615 \mathrm{lb} / \mathrm{hr}$ flue gas flow. The furnace was unable to operate solely on coal without natural gas support. The minimum co-firing using natural gas corresponds to approximately $100,000 \mathrm{Btu} / \mathrm{hr}$ of natural gas with the remainder of the thermal input being made up by coal. Approximately 10 to $15 \%$ dilution (on a mass basis) of natural gas was required to maintain stable furnace operation.

Inspection of the ash pit at the furnace bottom revealed that not all of the coal was being burned in the furnace. This was consistent with visual observation of the flame using sight ports in the furnace. The flame appeared rather long and extended downward into the lower portion of the furnace. Initial corrective action was focused on adjusting the swirl and flow characteristics of both combustion air and motive air (transport air) entering the furnace. This ultimately proved unsuccessful, and a determination was made that the size of the inlet motive air plumbing to the bumer and air flow were too large, resulting in excessive motive air velocity into the furnace. Installation of a smaller line along with decreasing the motive air flow appeared to correct the problem. 


\subsubsection{Flue Gas Coolers}

In shakedown period \#1, the flue gas exiting the furnace was excessively cooled in the water-jacket flue gas cooler. This resulted in insufficient process temperature $\left(550^{\circ} \mathrm{F}\right)$ at the absorber entrance. The heat exchanger was drained of water and insulation was added to maintain higher flue gas temperature reaching the absorber. This course of action was successful as demonstrated by a maximum flue gas temperature of $900^{\circ} \mathrm{F}$ maintained at one point in the absorber during the second shakedown period.

\subsubsection{Absorber}

The heaters on the absorber performed fairly well in unison. This is important in guarding against vessel warping due to large thermal gradients among the various heating zones. A maximum desired flue gas temperature of $900^{\circ} \mathrm{F}$ was obtained in the absorber by eliminating excessive flue gas cooling in the line between the furnace and the absorber.

A mechanical problem with the absorber assembly was discovered midway through the second shakedown period. Sorbent appeared in the outlet ash hopper of the absorber. The vessel was disassembled, and a gap was discovered at the top of the rear retention screen. The gap was caused by slight misalignment of the top sorbent inlet cone when it was initially assembled to the remaining vessel. Sorbent entering the top of the vessel through the sorbent inlet cone leaked behind the rear screen and flowed down through the pulser assembly and eventually into the rear ash hopper. Additional mechanical guides have been designed and attached to the sorbent cone to prevent any recurrence of the problem.

Once sorbent regeneration in the regenerator was initiated, $\mathrm{SO}_{2}$ removal chemistry in the absorber was confirmed. A baseline condition of $750^{\circ} \mathrm{F}$ in the absorber resulted in approximately $85 \% \quad \mathrm{SO}_{2}$ removal with an inlet $\mathrm{SO}_{2}$ level of approximately $1050 \mathrm{ppm}$. Eventually the gas spiking system for ammonia was initiated under similar conditions, and approximately $80 \% \mathrm{NO}_{\mathrm{x}}$ removal was observed in the absorber with an inlet $\mathrm{NO}_{x}$ level of approximately $525 \mathrm{ppm}$. The 1/16-in spheres of Grace sorbent used in the shakedown were sampled, drained, weighed, and stored.

\subsubsection{Sorbent Loop}

Sorbent flowed smoothly among the four main vessels. Process operation was initiated in the regenerator, absorber, fluidized-bed heater, fluidized-bed cooler, and incinerator. Maximum desired sorbent temperatures attained in the regenerator and absorber were $940^{\circ} \mathrm{F}$ and $900^{\circ} \mathrm{F}$, respectively. Sorbent flow was interrupted most often in the transport hopper used to pneumatically transport the sorbent 
from the absorber exit to the fluidized-bed heater. Considerable dust accumulated on the optical window used for level detection in the hopper. This dust (ash) buildup is consistent with the observation that the pressure drop increased across the front retention screen and/or front region of the bed. Once the sorbent was successfully navigated to the fluidized-bed heater, the dust was blown off and the remainder of the transport loop was relatively dust-free as evidenced by few problems encountered with the other sorbent hoppers. As a result of the transport hopper problems, the hopper is now being filled on a timed basis.

\subsubsection{Regenerator}

The regenerator operated fairly well and with no trouble. The vessel skin heaters performed adequately; a maximum desired process temperature of $950^{\circ} \mathrm{F}$ was demonstrated. With the absorber operating at $750^{\circ} \mathrm{F}$, natural gas (along with $\mathrm{N}_{2}$ dilution) was introduced into the regenerator operating at $850^{\circ} \mathrm{F}$.

A parametric step change was performed in which the molar ratio of $\mathrm{CH}_{4} / \mathrm{SO}_{2}$ was increased from 1 (theoretical amount of regeneration gas necessary to regenerate the sorbent) to 3.5 . Within 10 to 15 minutes, the offgas levels correspondingly increased, reflecting the additional regeneration of the sorbent. A second parametric test was conducted to examine the effect of not having $\mathrm{N}_{2}$ dilution of the regeneration gas. As expected, the product gases became more concentrated as $\mathrm{N}_{2}$ was eliminated. This experiment confirmed the ability to operate the regenerator solely with natural gas and no nitrogen dilution. A third parametric test involved increasing the regenerator temperature from $850^{\circ} \mathrm{F}$ to $950^{\circ} \mathrm{F}$ with pure natural gas regeneration (at $\mathrm{CH}_{4} / \mathrm{SO}_{2}$ equal to 3.5 ). 


\subsection{REFERENCES}

[1] U.S. Department of Energy, FY-1994 Program Implementation Plan for the Flue Gas Cleanup Program, December 1993.

[2] Ruth, L.A., and S.S. Kim, DOE/PETC Combustion 2000 Program. Proceedings of Ninth U.S.-Korea Joint Workshop on Coal Utilization Technology, pp 204-216, October 1992, San Francisco CA.

[3] Hoffman, J.S., Pennline, H.W., Yeh, J.T., Ratafia-Brown, J., and V.A. Gorokhov, Integration of a High Efficiency Flue Gas Cleanup Process Into Advanced Power Systems. Proceedings of the 19th International Technical Conference on Coal Utilization and Fuel Systems, pp 541-552, March 1994, Clearwater FL.

[4] Yeh, J.T., Hoffman, J.S., and Henry W. Pennline, Design of A Moving-Bed Copper Oxide Process For Simultaneous $\mathrm{SO}_{2}$ and $\mathrm{NO}_{x}$ Removal. Paper No. A682 presented at the 86th Annual AWMA Meeting, June 1993, Denver CO.

[5] Longton, E.J., Safety Analysis for the Copper Oxide Life Cycle Test System, U.S. DOE Contract No.DE-AC22-94PC92100, October 14, 1994.

[6] Gilbert Commonwealth Incorporated, Operating Procedure No. 88: Copper Oxide Life Cycle Test System Flue Gas Generation Process, October 1994, U.S.DOE Contract No. DE-AC2294PC92100.

[7] Gilbert Commonwealth Incorporated, Operating Procedure No. 89:

Copper Oxide Life Cycle Test System Absorption/Regeneration Process, November 1994, U.S.DOE Contract No. DE-AC22-94PC92100.

\subsection{ACKNOWLEDGEMENTS}

The authors wish to acknowledge the efforts of Atef G. Demian, Thomas Puglisi, and the Gilbert/Commonwealth, Inc., drafting group in the design phase; James Pschirer, William H. Brown, and the Gilbert/Commonwealth, Inc., technician crew in the construction and operations phase; and Nancy G. Carpenter for editorial assistance.

\subsection{DISCLAIMER}

Reference in this paper to any specific commercial product, process, or service is to facilitate understanding and does not necessarily imply its endorsement by the U.S. Department of Energy. 


\section{A.1 Air Corrections}

Following is the procedure for computing $\mathrm{SO}_{2}$ and $\mathrm{NO}_{x}$ concentrations at data stations around the absorber based on $20 \%$ dry excess combustion air ( $3.6 \%$ oxygen).

\section{A.1.1 Absorber Air In-Leakage}

The procedure starts by calculating air in-leakage, if any, between two data stations in a flue gas sample train. The following method is based on oxygen concentration change between these two sample points.

Let

$\mathrm{Al}=\mathrm{O}_{2}$ conc. at location 1 (upstream), in fraction

$\mathrm{A} 2=\mathrm{O}_{2}$ conc. at location 2 (downstream), in fraction

If $\mathrm{A} 2$ is greater than $\mathrm{Al}$, then some air in-leakage has occurred between location 1 and location 2. If $A 2$ is less than $A 1$ (which is physically impossible), no correction for air in-leakage is necessary but sources of possible error should be investigated. If $A 2$ is equal to $A 1$, then no leakage has occurred, and no leakage correction is necessary. The computational procedure for air in-leakage correction (if required) is as follows:

$\mathrm{D} 1$ = air in-leakage in fraction of original gas volume (volume fraction and mole fraction are identical for ideal gas assumption).

Then

$$
\begin{aligned}
& \mathrm{D} 1=(\mathrm{A} 2-\mathrm{A} 1) /(0.209-\mathrm{A} 2), \text { if } \mathrm{A} 2>\mathrm{A} 1 \\
& \mathrm{D} 1=0, \text { if } \mathrm{A} 2 \leq \mathrm{A} 1
\end{aligned}
$$

This equation physically implies that D1 moles of air have leaked into 1 mole of flue gas resulting in $(1+D 1)$ total moles. Species measurements for $\mathrm{SO}_{2}$ and $\mathrm{NO}_{x}$ at the absorber outlet (flow sampling station $\# 2$ or $\mathbf{S} 2$ in Figure 1) are adjusted for leakage using the following:

$$
\begin{aligned}
& \mathrm{SO}_{2}^{\mathrm{s} 2}(\operatorname{adj})=\mathrm{SO}_{2}^{\mathrm{s} 2}(1+\mathrm{D} 1) \\
& \mathrm{NO}_{x}^{\mathrm{s} 2}(\operatorname{adj})=\mathrm{NO}_{x}^{\mathrm{s} 2}(1+\mathrm{D} 1)
\end{aligned}
$$

\section{A.1.2 Combustion Air Conrection}

If the overall stoichiometry of fuel and air in the furnace differs from the defined baseline of $20 \%$ excess combustion air (which corresponds to $3.6 \%$ oxygen in the flue gas), an additional correction to species measurements at the absorber inlet and outlet is necessary. Combustion air is added (or subtracted) from the furnace inlet to achieve a desired excess air level. Thus, the 
above calculational procedure used for absorber in-leakage can analogously be used to correct species measurements to correspond to a baseline $20 \%$ excess air level. The correction is applicable to absorber inlet (S1) and absorber outlet (S2) flow stations. The actual oxygen measurement at the absorber inlet $\left(\mathrm{O}_{2}{ }^{\mathrm{Sl}}\right)$ must be compared to the baseline oxygen level (3.6\%). Depending on which is greater, different formulations of the problem are required. If the absorber inlet oxygen level $\left(\mathrm{O}_{2}^{\mathrm{sl}}\right)$ is greater than $3.6 \%$, then:

$\mathrm{Al}=\mathrm{O}_{2}$ conc. at location 1 (upstream) $=3.6 \%$

$\mathrm{A} 2=\mathrm{O}_{2}$ conc. at location 2 (downstream) $=\mathrm{O}_{2}$ level @ absorber inlet $=\mathrm{O}_{2}^{\mathrm{sl}}$

Let

$\mathrm{D} 1_{\mathrm{Ex}}=$ excess air in-leakage in fraction of original gas volume

Then

$$
\mathrm{Dl}_{\mathrm{Bx}}=(\mathrm{A} 2-\mathrm{A} 1) /(0.209-\mathrm{A} 2), \text { if } \mathrm{O}_{2}^{\mathrm{S1}}>3.6 \%
$$

This equation implies that $\mathrm{D} 1_{\mathrm{Ex}}$ moles of air have leaked into 1 mole of flue gas, which results in $\left(1+\mathrm{Dl}_{\mathrm{Bx}}\right)$ total moles. Species measurements for $\mathrm{SO}_{2}$, and $\mathrm{NO}_{\mathrm{x}}$ at the absorber inlet and absorber outlet are corrected for excess air using (if $\mathrm{O}_{2}{ }^{\mathrm{SI}}>3.6 \%$ ):

$$
\begin{aligned}
& \mathrm{SO}_{2}^{\mathrm{S1}}(\mathrm{Ex} / \mathrm{adj})=\mathrm{SO}_{2}^{\mathrm{S1}}\left(1+\mathrm{Dl}_{\mathrm{Ex}}\right) \\
& \mathrm{NO}_{\mathrm{x}}^{\mathrm{S1}}(\mathrm{Ex} / \mathrm{adj})=\mathrm{NO} \mathrm{O}_{\mathrm{x}}^{\mathrm{s} 1}\left(1+\mathrm{D} 1_{\mathrm{Bx}}\right) \\
& \mathrm{SO}_{2}^{\mathrm{S2}}(\mathrm{Ex} / \mathrm{adj})=\mathrm{SO}_{2}^{\mathrm{S} 2}(\mathrm{adj})^{*}\left(1+\mathrm{D} 1_{\mathrm{Ex}}\right)=\mathrm{SO}_{2}^{\mathrm{S} 2}(1+\mathrm{D} 1)\left(1+\mathrm{D} 1_{\mathrm{Bx}}\right) \\
& \mathrm{NO}_{\mathrm{x}}^{\mathrm{S2}}(\mathrm{Ex} / \mathrm{adj})=\mathrm{NO}_{\mathrm{x}}^{\mathrm{S2}}(\operatorname{adj})^{*}\left(1+\mathrm{D} 1_{\mathrm{Bx}}\right)=N \mathrm{NO}_{\mathrm{x}}^{\mathrm{S} 2}(1+\mathrm{D} 1)\left(\mathrm{I}+\mathrm{D} 1_{\mathrm{Bx}}\right)
\end{aligned}
$$

The formulation of the problem is reversed if the absorber inlet oxygen level $\left(\mathrm{O}_{2}^{\mathrm{sl}}\right)$ is less than $3.6 \%$ :

Let

$\mathrm{Al}=\mathrm{O}_{2}$ conc. at location 1 (upstream) $=\mathrm{O}_{2}$ level @ absorber inlet $=\mathrm{O}_{2}^{\mathrm{sl}}$

$\mathrm{A} 2=\mathrm{O}_{2}$ conc. at location 2 (downstream) $=3.6 \%$

$\mathrm{D} 1_{\mathrm{Ex}}=$ excess air in-leakage in fraction of original gas volume

Then

$$
\mathrm{D} 1_{\mathrm{Bx}}=(\mathrm{A} 2-\mathrm{A} 1) /(0.209-\mathrm{A} 2), \text { if } \mathrm{O}_{2}^{\mathrm{S} 1}<3.6 \%
$$

This equation implies that $\mathrm{Dl}_{\mathrm{Bx}}$ moles of air have leaked into 1 mole of flue gas, which results in $\left(1+\mathrm{Dl}_{\mathrm{Ex}}\right)$ total moles. Species measurements for $\mathrm{SO}_{2}$ and $\mathrm{NO}_{\mathrm{x}}$ at the absorber inlet and absorber outlet are corrected for excess air using (if $\mathrm{O}_{2}{ }^{\mathrm{Sl}}<3.6 \%$ ): 


$$
\begin{aligned}
& \mathrm{SO}_{2}{ }^{\mathrm{S1}}(\mathrm{Ex} / \mathrm{adj})=\mathrm{SO}_{2}{ }^{31} /\left(1+\mathrm{Dl}_{\mathrm{Bx}}\right) \\
& \mathrm{NO}_{\mathrm{x}}^{\mathrm{s1}}(\mathrm{Ex} / \mathrm{adj})=\mathrm{NO}_{\mathrm{x}}^{\mathrm{s}} /\left(1+\mathrm{D} 1_{\mathrm{Bx}}\right) \\
& \mathrm{SO}_{2}^{\mathrm{S2}}(\mathrm{Ex} / \mathrm{adj})=\mathrm{SO}_{2}^{\mathrm{S} 2}(\operatorname{adj}) /\left(1+\mathrm{Dl}_{\mathrm{Bx}}\right)=\mathrm{SO}_{2}^{\mathrm{S2}}(1+\mathrm{D} 1) /\left(1+\mathrm{D} 1_{\mathrm{Ex}}\right) \\
& \mathrm{NO}_{\mathrm{x}}^{\mathrm{s} 2}(\mathrm{Ex} / \mathrm{adj})=\mathrm{NO}_{\mathrm{x}}^{\mathrm{s2}}(\text { adj }) /\left(1+\mathrm{D} 1_{\mathrm{Bx}}\right)=\mathrm{NO}_{\mathrm{x}}^{\mathrm{s} 2}(1+\mathrm{D} 1) /\left(1+\mathrm{D} 1_{\mathrm{Ex}}\right)
\end{aligned}
$$

\begin{tabular}{|c|}
\hline If $\mathrm{O}_{2}^{\mathrm{si}}>3.6 \%$ \\
\hline $\mathrm{SO}_{2}^{\mathrm{S1}}(\mathrm{Ex} / \mathrm{adj})=\mathrm{SO}_{2}^{\mathrm{S1}}\left(1+\mathrm{Dl}_{\mathrm{Bx}}\right)$ \\
\hline $\mathrm{D} 1_{\mathrm{Bx}}=\left(\mathrm{O}_{2}^{\mathrm{s1}}-0.036\right) /\left(0.209-\mathrm{O}_{2}^{\mathrm{s1}}\right)$ \\
\hline $\mathrm{SO}_{2}^{\mathrm{s1}}(\mathrm{Ex} / \mathrm{adj})=\mathrm{SO}_{2}^{\mathrm{s}}\left[1+\left(\mathrm{O}_{2}^{\mathrm{s1}}-0.036\right) /\left(0.209-\mathrm{O}_{2}^{\mathrm{s1}}\right)\right]$ \\
\hline If $\mathrm{O}_{2}^{\mathrm{s1}}<3.6 \%$ \\
\hline $\mathrm{SO}_{2}{ }^{\mathrm{S1}}(\mathrm{Ex} / \mathrm{adj})=\mathrm{SO}_{2}{ }^{\mathrm{S1}} /\left(1+\mathrm{Dl}_{\mathrm{nz}}\right)$ \\
\hline $\mathrm{D} 1_{\mathrm{Bx}}=\left(0.036-\mathrm{O}_{2}^{\mathrm{S1}}\right) /(0.209-0.036)$ \\
\hline $\mathrm{SO}_{2}^{\mathrm{s1}}(\mathrm{Ex} / \mathrm{adj})=\mathrm{SO}_{2}^{\mathrm{S1}} /\left[1+\left(0.036-\mathrm{O}_{2}^{\mathrm{s1}}\right) /(0.209-0.036)\right]$ \\
\hline
\end{tabular}

Closer examination of the two cases for deviation from the stoichiometric setpoint $\left(\mathrm{O}_{2}{ }^{\mathrm{S1}}\right.$ not equal to $3.6 \%$ ) reveals simplification in the required number of equations. As an example, the two sets of equations describing stoichiometric correction to the absorber inlet $\mathrm{SO}_{2}$ levels are as follows:

It can be shown that the algebraic expressions used to correct $\mathrm{SO}_{2}^{\mathrm{S1}}$ are identical. The expression for the second case can be simplified as follows:

$$
\begin{aligned}
& 1 /\left[1+\left(0.036-\mathrm{O}_{2}{ }^{\mathrm{S1}}\right) /(0.209-0.036)\right]=1 /\left[\left(0.209-0.036+0.036-\mathrm{O}_{2}{ }^{\mathrm{S1}}\right) /(0.209-0.036)\right] \\
& =1 /\left[\left(0.209-\mathrm{O}_{2}^{\mathrm{s} 1}\right) /(0.209-0.036)\right] \\
& =(0.209-0.036) /\left(0.209-\mathrm{O}_{2}{ }^{\mathrm{s1}}\right) \\
& =\left(0.209-\mathrm{O}_{2}^{\mathrm{S1}}+\mathrm{O}_{2}^{\mathrm{S1}}-0.036\right) /\left(0.209-\mathrm{O}_{2}^{\mathrm{S1}}\right) \\
& =1+\left(\mathrm{O}_{2}^{\mathrm{S1}}-0.036\right) /\left(0.209-\mathrm{O}_{2}^{\mathrm{s1}}\right) \\
& =\text { first case correction term for } \mathrm{SO}_{2}{ }^{\mathrm{S} 1}
\end{aligned}
$$

Since both cases are equivalent, the first case form for stoichiometric correction will be used for all values of oxygen levels not equal to the stoichiometric setpoint $\left(\mathrm{O}_{2}{ }^{\mathrm{s1}}=3.6 \%\right)$. Species measurements for $\mathrm{SO}_{2}$ and $\mathrm{NO}_{x}$ at the absorber inlet and absorber outlet are corrected for excess air using the following: 


$$
\begin{aligned}
& \mathrm{SO}_{2}^{\mathrm{Sl}}(\mathrm{Ex} / \mathrm{adj})=\mathrm{SO}_{2}^{\mathrm{Sl}}\left(1+\mathrm{Dl}_{\mathrm{Ex}}\right) \\
& \mathrm{NO}_{x}^{\mathrm{S1}}(\mathrm{Ex} / \mathrm{adj})=\mathrm{NO}_{x}^{\mathrm{sl}}\left(1+\mathrm{D} 1_{\mathrm{Ex}}\right) \\
& \mathrm{SO}_{2}^{\mathrm{S2}}(\mathrm{Ex} / \mathrm{adj})=\mathrm{SO}_{2}^{\mathrm{S} 2}(\mathrm{adj}) *\left(1+\mathrm{Dl}_{\mathrm{Bx}}\right)=\mathrm{SO}_{2}^{\mathrm{S} 2}(1+\mathrm{D} 1)\left(1+\mathrm{Dl}_{\mathrm{Ex}}\right) \\
& \mathrm{NO}_{\mathrm{x}}^{\mathrm{S} 2}(\mathrm{Ex} / \mathrm{adj})=\mathrm{NO}_{\mathrm{x}}^{\mathrm{S} 2}(\mathrm{adj})^{*}\left(1+\mathrm{D} 1_{\mathrm{Bx}}\right)=\mathrm{NO}_{\mathrm{x}}^{\mathrm{S} 2}(1+\mathrm{D} 1)\left(1+\mathrm{D} 1_{\mathrm{Zx}}\right)
\end{aligned}
$$

In summary, two adjustments to species measurements for absorber inlet and outlet flow stations can occur. The first adjustment (D1) takes into account any air in-leakage to the absorber. The second adjustment $\left(\mathrm{Dl}_{\mathrm{Bx}}\right)$ places the measurements on a constant oxygen basis of $3.6 \%$ (corresponding to $20 \%$ excess air). Since both of these corrections have similar algebraic form and are multiplicative when performing the species adjustment, additional simplification of the equations is possible. Consider the correction for $\mathrm{SO}_{2}$ at the absorber inlet:

$$
\begin{aligned}
\mathrm{SO}_{2}{ }^{\mathrm{S1}}(\mathrm{Ex} / \mathrm{adj}) & =\mathrm{SO}_{2}^{\mathrm{S1}}\left(1+\mathrm{Dl}_{\mathrm{EL}}\right) \\
& =\mathrm{SO}_{2}{ }^{\mathrm{S1}}\left[1+\left(\mathrm{O}_{2}{ }^{\mathrm{ll}}-0.036\right) /\left(0.209-\mathrm{O}_{2}^{\mathrm{S1}}\right)\right]
\end{aligned}
$$

Consider the correction for $\mathrm{SO}_{2}$ at the absorber outlet:

$$
\begin{aligned}
& \mathrm{SO}_{2}^{\mathrm{S2}}(\mathrm{Ex} / \mathrm{adj})=\mathrm{SO}_{2}^{\mathrm{S} 2}(1+\mathrm{D} 1)\left(1+\mathrm{Dl}_{\mathrm{BH}}\right) \\
& =\mathrm{SO}_{2}^{\mathrm{S2}}\left[1+\left(\mathrm{O}_{2}^{\mathrm{S2}}-\mathrm{O}_{2}^{\mathrm{S1}}\right) /\left(0.209-\mathrm{O}_{2}^{\mathrm{S2}}\right)\right]^{\mathrm{S}}\left[1+\left(\mathrm{O}_{2}^{\mathrm{S1}}-0.036\right) /\left(0.209-\mathrm{O}_{2}^{\mathrm{SI}}\right)\right] \\
& =\mathrm{SO}_{2}{ }^{\mathrm{S2}}\left[\left(0.209-\mathrm{O}_{2}{ }^{\mathrm{s2}}+\mathrm{O}_{2}^{\mathrm{s2}}-\mathrm{O}_{2}^{\mathrm{S1}}\right) /\left(0.209-\mathrm{O}_{2}^{\mathrm{s2}}\right)\right]^{*}\left[\left(0.209-\mathrm{O}_{2}{ }^{\mathrm{S1}}+\mathrm{O}_{2}{ }^{\mathrm{s1}}-0.036\right) /\left(0.209-\mathrm{O}_{2}^{\mathrm{S1}}\right)\right] \\
& =\mathrm{SO}_{2}^{\mathrm{S2}}\left[\left(0.209-\mathrm{O}_{2}^{\mathrm{S1}}\right) /\left(0.209-\mathrm{O}_{2}^{\mathrm{S2}}\right)\right]^{*}\left[(0.209-0.036) /\left(0.209-\mathrm{O}_{2}^{\mathrm{S1}}\right)\right] \\
& =\mathrm{SO}_{2}^{\mathrm{S2}}\left[(0.209-0.036) /\left(0.209-\mathrm{O}_{2}^{\mathrm{S2}}\right)\right] \\
& =\mathrm{SO}_{2}^{\mathrm{S2}}\left[\left(0.209-\mathrm{O}_{2}^{\mathrm{S2}}+\mathrm{O}_{2}^{\mathrm{s2}}-0.036\right) /\left(0.209-\mathrm{O}_{2}^{\mathrm{S2}}\right)\right] \\
& =\mathrm{SO}_{2}^{\mathrm{S2}}\left[1+\left(\mathrm{O}_{2}^{\mathrm{S2}}-0.036\right) /\left(0.209-\mathrm{O}_{2}^{\mathrm{S} 2}\right)\right]
\end{aligned}
$$

Thus, the correction for $\mathrm{SO}_{2}$ at the absorber outlet is identical in form to the correction at the absorber inlet, and the corresponding oxygen level is utilized in each equation. Hence, one correction (to account for absorber in-leakage and/or deviation from the stoichiometric setpoint $\left.\left[\mathrm{O}_{2}{ }^{\mathrm{Sl}}=3.6 \%\right]\right)$ can be used. Species measurements for $\mathrm{SO}_{2}$ and $\mathrm{NO}_{\mathrm{x}}$ at the absorber inlet and absorber outlet are corrected using the below equations appearing in final form:

$$
\begin{aligned}
& \mathrm{SO}_{2}{ }^{\mathrm{S1}}(\mathrm{cor})=\mathrm{SO}_{2}{ }^{\mathrm{S1}}\left[1+\left(\mathrm{O}_{2}^{\mathrm{S1}}-0.036\right) /\left(0.209-\mathrm{O}_{2}^{\mathrm{S} 1}\right)\right] \\
& \mathrm{NO}_{x}^{\mathrm{SI}}(\mathrm{cor})=\mathrm{NO}_{x}^{\mathrm{S1}}\left[1+\left(\mathrm{O}_{2}^{\mathrm{Sl}}-0.036\right) /\left(0.209-\mathrm{O}_{2}^{\mathrm{SI}}\right)\right] \\
& \mathrm{SO}_{2}^{\mathrm{S2}} \text { (cor) }=\mathrm{SO}_{2}^{\mathrm{S2}}\left[1+\left(\mathrm{O}_{2}^{\mathrm{S2}}-0.036\right) /\left(0.209-\mathrm{O}_{2}^{\mathrm{S2}}\right)\right] \\
& \mathrm{NO}_{\mathrm{x}}^{\mathrm{S2}}(\mathrm{cor})=\mathrm{NO}_{\mathrm{x}}^{\mathrm{S} 2}\left[1+\left(\mathrm{O}_{2}^{\mathrm{S} 2}-0.036\right) /\left(0.209-\mathrm{O}_{2}^{\mathrm{S} 2}\right)\right]
\end{aligned}
$$

All pollutant removals in the absorber will be calculated using adjusted species values. 


\section{A.2 Equations for Data Analysis}

\section{A.2.1 $\quad \mathrm{SO}_{2}$ Removal Efficiency, $(\%)=\mathrm{E} 1$}

This is a measure of $\mathrm{SO}_{2}$ removal efficiency of the absorber. The flue gas samples are assumed to have received similar sample treatments and similar analyzers are used.

$$
\begin{aligned}
\mathrm{E} 1 & =\frac{100 \text { (inlet } \mathrm{SO}_{2} \text { conc. [cor] to absorber - outlet } \mathrm{SO}_{2} \text { conc. [cor] from absorber) }}{\text { inlet } \mathrm{SO}_{2} \text { conc. [cor] to absorber }} \\
& =\frac{100\left[\mathrm{SO}_{2}^{\mathrm{S} 1}(\mathrm{cor})-\mathrm{SO}_{2}^{\mathrm{S} 2}(\mathrm{cor})\right]}{\mathrm{SO}_{2}^{\mathrm{S1}}(\mathrm{cor})}
\end{aligned}
$$

\section{A.2.2 NO Removal Efficiency, $(\%)=\mathbf{E 2}$}

This is a measure of $\mathrm{NO}_{\mathrm{x}}$ removal efficiency of the absorber. The flue gas samples are assumed to have received similar sample treatments and similar analyzers are used.

$$
\begin{aligned}
\mathrm{E} 2 & =\frac{100 \text { (inlet } \mathrm{NO}_{\mathrm{x}} \text { conc. [cor] to absorber - outlet } \mathrm{NO}_{\mathrm{x}} \text { conc. [cor] from absorber) }}{\text { inlet } \mathrm{NO}_{\mathrm{x}} \text { conc. [cor] to absorber }} \\
& =\frac{100\left[\mathrm{NO}_{\mathrm{x}}^{\mathrm{s}}(\mathrm{cor})-\mathrm{NO}_{\mathrm{x}}^{\mathrm{S2}}(\mathrm{cor})\right]}{\mathrm{NO}_{\mathrm{x}}^{\mathrm{s}}(\mathrm{cor})}
\end{aligned}
$$

\section{A.2.3 Air-to-Cloth Ratio (Flue Gas to Absorber CS Area), ft/min = ACR}

This is defined as ratio of the flue gas volumetric flow rate to the cross sectional area of the moving bed.

$$
\begin{aligned}
\mathrm{ACR} & =\frac{\text { flue gas flow rate, } \mathrm{ft}^{3} / \mathrm{min}}{\text { absorber cross sect. area, } \mathrm{ft}^{2}} \\
& =\frac{\text { flue gas flow rate, SCFM] } \left.\mathrm{P}_{\mathrm{s}} / \mathrm{P}\right]\left[\mathrm{T} / \mathrm{T}_{\mathrm{s}}\right]}{\text { absorber cross sect. area, } \mathrm{ft}^{2}} \\
& =\frac{[\text { flue gas flow rate, } \mathrm{SCFM}][1 \text { ATM/P][T/520 } \mathrm{R}]}{\text { absorber cross sect. area, } \mathrm{ft}^{2}}
\end{aligned}
$$




\section{A.2.4 Apparent Gas Residence Time in Absorber, sec $=$ GRT}

This is defined as the time required for the flue gas to pass through the bed of sorbent in a cross flow.

$$
\begin{aligned}
\text { GRT } & =\frac{\text { sorbent thickness, in }}{\text { gas cross-flow velocity, in } / \mathrm{sec}} \\
& =\frac{\text { sorbent thickness, in }}{[\text { Air-to-Cloth Ratio, } \mathrm{ft} / \mathrm{min}][12 \mathrm{in} / \mathrm{ft}][1 \mathrm{~min} / 60 \mathrm{sec}]} \\
& =\frac{[\text { sorbent thickness, } \mathrm{in}][60 \mathrm{sec} / \mathrm{min}]}{[\mathrm{ACR}, \mathrm{ft} / \mathrm{min}][12 \mathrm{in} / \mathrm{ft}]}
\end{aligned}
$$

\section{A.2.5 Absorber Sorbent Residence Time, $\min =\mathbf{A R T}$}

This is defined as the time elapsed between sorbent inlet to the absorber and sorbent outlet from the absorber.

$$
\text { ART }=\frac{\text { absorber sorbent inventory, } \mathrm{lb}}{\text { sorbent feed rate, } \mathrm{lb} / \mathrm{min}}
$$

\section{A.2.6 Regenerator Sorbent Residence Time, $\min =\mathbf{R R T}$}

This is defined as the average time elapsed between sorbent inlet to the regenerator and sorbent outlet from the regenerator.

$$
\mathrm{RRT}=\frac{\text { regenerator sorbent inventory, } \mathrm{lb}}{\text { sorbent feed rate, } \mathrm{lb} / \mathrm{min}}
$$

\section{A.2.7 Fluidized-bed Cooler Sorbent Residence Time, $\min =\mathbf{C R T}$}

This is the average elapsed time between sorbent inlet to the fluidized-bed cooler and the outlet from the cooler.

$$
\mathrm{CRT}=\frac{\text { Cooler sorbent inventory, } \mathrm{lb}}{\text { sorbent feed rate, } \mathrm{lb} / \mathrm{min}}
$$




\section{A.2.8 Fluidized-bed Heater Sorbent Residence Time, min $=$ HRT}

This is the average elapsed time between sorbent inlet to the fluidized-bed heater and the outlet from the heater.

$$
\text { HRT }=\frac{\text { heater sorbent inventory, } \mathrm{lb}}{\text { sorbent feed rate, } \mathrm{lb} / \mathrm{min}}
$$

\section{A.2.9 Total Cu to S Molar Ratio $=$ N2}

This is the ratio of total copper flow rate (moles per min) through the absorber to the $\mathrm{SO}_{2}$ flow rate (moles per $\mathrm{min}$ ) through the absorber. All copper content impregnated into the sorbent is used in the calculation.

$$
\begin{aligned}
& \mathrm{Cu} \text { flow rate, } \mathrm{lb}-\mathrm{mol} / \mathrm{min} \\
& \mathrm{N} 2=\overline{\mathrm{S} \text { flow rate, } \mathrm{lb}-\mathrm{mol} / \mathrm{min}} \\
& \mathrm{Cu}=\frac{\text { [sorbent flow rate, } \mathrm{lb} / \mathrm{min}][\mathrm{Cu} \text { mass fraction in sorbent }]}{[\mathrm{MW} \mathrm{Cu}, \mathrm{lb} / \mathrm{bb}-\mathrm{mol}]} \\
& \text { [sorbent flow rate, } \mathrm{lb} / \mathrm{min}][\mathrm{Cu} \text { mass fraction in sorbent] } \\
& = \\
& {[63.54 \mathrm{lb} / \mathrm{lb}-\mathrm{mol}]} \\
& \text { [flue gas, scfm][SO } \mathrm{SO}_{2} \text { conc, ppm] } \\
& S= \\
& \text { [gas molar volume@STP, } \left.\mathrm{ft}^{3} / \mathrm{lb}-\mathrm{mol}\right]\left[10^{6}\right] \\
& =\frac{[\text { flue gas, scfm }]\left[\mathrm{SO}_{2}^{\mathrm{s}}, \mathrm{ppm}\right]}{\left[379 \mathrm{ft}^{3} / \mathrm{bb}-\mathrm{mol}\right]\left[10^{6} \mathrm{ppm}\right]} \\
& \mathrm{N} 2=\frac{[\text { sorbent flow rate, } \mathrm{lb} / \mathrm{min}][\mathrm{Cu} \text { mass fraction in sorbent }] /[63.54 \mathrm{lb} / \mathrm{lb}-\mathrm{mol}]}{[\text { flue gas, } \mathrm{scfm}]\left[\mathrm{SO}_{2}^{\mathrm{s} 1}, \mathrm{ppm}\right] /\left[379 \mathrm{ft}^{3} / \mathrm{bb}-\mathrm{mol}\right] /\left[10^{6} \mathrm{ppm}\right]}
\end{aligned}
$$

\section{A.2.10 Available Cu (wt\%) $=$ N3}

This is the total amount of copper on the sorbent entering the absorber that is available for chemical reaction with $\mathrm{SO}_{2}$. The calculation is based on the total amount of copper on the sorbent less the amount of copper in the form of unregenerated $\mathrm{CuSO}_{4}$ and $\mathrm{Cu}_{2} \mathrm{~S}$. 
$\mathrm{N} 3=($ total $\mathrm{Cu}$ on sorbent, wt\%) $-($ unregenerated $\mathrm{Cu}, \mathrm{wt} \%)$

(total $\mathrm{CuSO}_{4}$ on sorbent into absorber, wt\%)[MW Cu, $\left.\mathrm{lb} / \mathrm{lb}-\mathrm{mol}\right]$

unreg $\left.\mathrm{Cu}, \ddot{w} t \%=\frac{}{[\mathrm{MW} \mathrm{CuSO}}{ }_{4}, \mathrm{lb} / \mathrm{lb}-\mathrm{mol}\right]$
(total $\mathrm{Cu}_{2} \mathrm{~S}$ on sorbent into absorber,wt\%)[2 $\left.\mathrm{MW} \mathrm{Cu}, \mathrm{lb} / \mathrm{lb}-\mathrm{mol}\right]$
$+$
$\left[\mathrm{MW} \mathrm{Cu} \mathrm{Cu}_{2} \mathrm{~S}, \mathrm{lb} / \mathrm{lb}-\mathrm{mol}\right]$

unreg $\mathrm{Cu}, \mathrm{wt} \%=$

(total $\mathrm{CuSO}_{4}$ on sorbent into absorber, wt\%)[63.54 lb/lb-mol]

$$
\text { [159.60 lb/lb-mol] }
$$

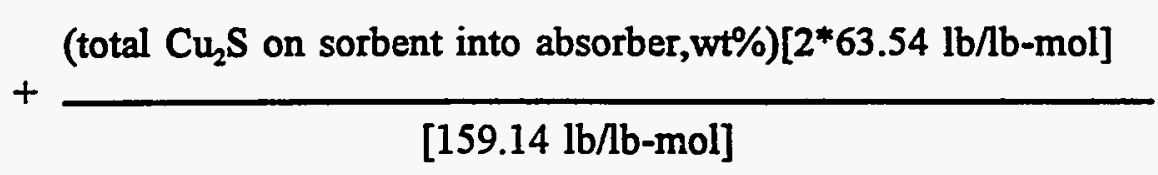

\section{A.2.11 Available Cu/S Molar Ratio $=$ N4}

$$
\mathrm{N} 4=\frac{\mathrm{Av} \mathrm{Cu} \text { flow rate, } \mathrm{lb}-\mathrm{mol} / \mathrm{min}}{\mathrm{S} \text { flow rate, } \mathrm{lb}-\mathrm{mol} / \mathrm{min}}
$$$$
\mathrm{Av} \mathrm{Cu}=\frac{\text { [sorbent flow rate, } \mathrm{lb} / \mathrm{min}][\mathrm{Av} \mathrm{Cu} \text { in sorbent, Wt Fract] }}{[\mathrm{MW} \mathrm{Cu}, \mathrm{lb} / \mathrm{lb}-\mathrm{mol}]}
$$$$
=\underline{\text { [sorbent flow rate, lb/min] } \mathrm{Av} \mathrm{Cu} \text { in sorbent, Wt Fract] }}
$$$$
\text { [63.54 lb/lb-mol] }
$$$$
\mathrm{S}=\frac{[\text { flue gas, } \mathrm{scfm}]\left[\mathrm{SO}_{2} \text { conc, ppm }\right]}{\left[\text { gas molar volume @ STP, } \mathrm{ft}^{3} / \mathrm{bb}-\mathrm{mol}\right]\left[10^{6}\right]}
$$$$
=\frac{[\text { flue gas, scfm }]\left[\mathrm{SO}_{2}^{\mathrm{si}}, \mathrm{ppm}\right]}{\left[379 \mathrm{ft}^{3} / \mathrm{bb}-\mathrm{mol}\right]\left[10^{6} \mathrm{ppm}\right]}
$$

$\mathrm{N} 4=\frac{[\text { sorbent flow rate, } \mathrm{lb} / \mathrm{min}][\mathrm{Av} \mathrm{Cu} \text { in sorbent, Wt Fract }] /[63.54 \mathrm{lb} / \mathrm{lb}-\mathrm{mol}]}{[\text { flue gas, } \mathrm{scfm}]\left[\mathrm{SO}_{2}^{\mathrm{s1}}, \mathrm{ppm}\right] /\left[379 \mathrm{ft}^{3} / \mathrm{lb}-\mathrm{mol}\right] /\left[10^{6} \mathrm{ppm}\right]}$ 
Only regenerated copper is taken into consideration in the calculation.

\section{A.2.12 Moles $\mathrm{SO}_{2}$ Removed Per Mole Total $\mathrm{Cu}=\mathrm{N5}$}

$$
\begin{aligned}
& \mathrm{SO}_{2} \text { removed, } \mathrm{mol} / \mathrm{min} \\
& \mathrm{N} 5=\frac{}{\text { total } \mathrm{Cu} \text { in circulation, } \mathrm{mol} / \mathrm{min}}
\end{aligned}
$$

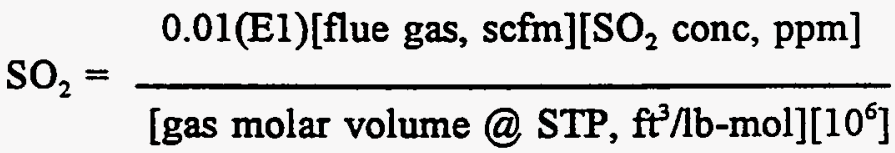

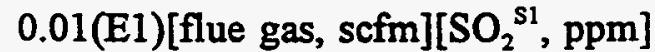

$$
\begin{aligned}
& = \\
& {\left[379 \mathrm{ft}^{3} / \mathrm{hb}-\mathrm{mol}\right]\left[10^{6} \mathrm{ppm}\right]} \\
& \mathrm{Cu}=\frac{\text { [sorbent flow rate, } \mathrm{lb} / \mathrm{min}][\mathrm{Cu} \text { mass fraction in sorbent }]}{[\mathrm{MW} \mathrm{Cu}, \mathrm{lb} / \mathrm{b}-\mathrm{mol}]} \\
& \text { [sorbent flow rate, } \mathrm{lb} / \mathrm{min}][\mathrm{Cu} \text { mass fraction in sorbent] } \\
& =\frac{[63.54 \mathrm{lb} / \mathrm{lb}-\mathrm{mol}]}{} \\
& \mathrm{N} 5=\frac{0.01(\mathrm{E} 1)[\text { flue gas, } \mathrm{scfm}]\left[\mathrm{SO}_{2}^{\mathrm{S1}}, \mathrm{ppm}\right] /\left[379 \mathrm{ft}^{3} / \mathrm{lb}-\mathrm{mol}\right] /\left[10^{6} \mathrm{ppm}\right]}{[\text { sorbent flow rate, } \mathrm{lb} / \mathrm{min}][\mathrm{Cu} \text { mass fraction in sorbent }] /[63.54 \mathrm{lb} / \mathrm{b}-\mathrm{mol}]}
\end{aligned}
$$

\section{A.2.13 Moles $\mathrm{SO}_{2}$ removed per mole available $\mathrm{Cu}=\mathrm{N} 51$}

$$
\begin{aligned}
\mathrm{N} 51 & =\frac{\mathrm{mol} / \mathrm{min} \mathrm{SO}_{2} \text { removed }}{\mathrm{mol} / \mathrm{min} \text { available } \mathrm{Cu} \text { in circulation }} \\
\mathrm{SO}_{2} & =\frac{0.01(\mathrm{E} 1)[\text { flue gas, scfm }]\left[\mathrm{SO}_{2} \text { conc, ppm }\right]}{\left[\text { gas molar volume @ } \mathrm{STP}, \mathrm{ft}^{3} / \mathrm{lb}-\mathrm{mol}\right]\left[10^{6}\right]} \\
& =\frac{0.01(\mathrm{E} 1)[\mathrm{flue} \text { gas, } \mathrm{scfm}]\left[\mathrm{SO}_{2}^{\mathrm{s1}}, \mathrm{ppm}\right]}{\left[379 \mathrm{ft}^{3} / \mathrm{lb}-\mathrm{mol}\right]\left[10^{6} \mathrm{ppm}\right]}
\end{aligned}
$$




$$
\begin{aligned}
\operatorname{Av} \mathrm{Cu} & =\frac{\text { [sorbent flow rate, } \mathrm{lb} / \mathrm{min}][\mathrm{Av} \mathrm{Cu} \text { in sorbent, Wt Fract }]}{[\mathrm{MW} \mathrm{Cu}, \mathrm{lb} / \mathrm{lb}-\mathrm{mol}]} \\
& =\frac{[\text { sorbent flow rate, } \mathrm{lb} / \mathrm{min}][\mathrm{N} 3 / 100]}{[63.54 \mathrm{lb} / \mathrm{lb}-\mathrm{mol}]} \\
\mathrm{N} 51 & =\frac{0.01(\mathrm{E} 1)[\text { flue gas, } \mathrm{scfm}]\left[\mathrm{SO}_{2}^{\mathrm{s} 1}, \mathrm{ppm}\right] /\left[379 \mathrm{ft}^{3} / \mathrm{lb}-\mathrm{mol}\right] /\left[10^{6} \mathrm{ppm}\right]}{[\text { sorbent flow rate, } \mathrm{lb} / \mathrm{min}][\mathrm{N} 3 / 100] /[63.54 \mathrm{lb} / \mathrm{bb}-\mathrm{mol}]}
\end{aligned}
$$

\section{A.2.14 Lb Sorbent $1000 \mathrm{scf}$ Flue Gas $=$ N6}

This calculation normalizes the effects of variance in sorbent circulation rate and flue gas rate so that comparisons can be made on a common basis. This number provides an indication of the effectiveness of the sorbent circulation rate.

$$
\begin{aligned}
\mathrm{N} 6 & =\frac{\text { (sorbent circulation rate, } \mathrm{lb} / \mathrm{min} \text { ) }}{\text { (flue gas flow, } 10^{3} \mathrm{scfm} \text { ) }} \\
& =\frac{\text { (sorbent circulation rate, } \mathrm{lb} / \mathrm{min} \text { ) }}{\text { (flue gas flow, } \mathrm{scfm}) /(1000)}
\end{aligned}
$$

\section{A.2.15 $\mathrm{NH}_{3} / \mathrm{NO}_{\mathbf{x}}$ Molar Ratio $=\mathrm{M1}$}

This is the molar ratio between molar flow rate of ammonia to molar flow rate of $\mathrm{NO}_{\mathrm{x}}$ into the absorber.

$$
\begin{aligned}
\mathrm{M} 1 & =\frac{\left(\mathrm{NH}_{3} \text { to absorber, scfm }\right)}{\left(\mathrm{NO}_{\mathrm{x}} \text { to absorber, } \mathrm{scfm}\right)} \\
& =\frac{\left(\mathrm{NH}_{3} \text { to absorber, scfm }\right)}{[\text { flue gas, scfm }]\left[\mathrm{NO}_{\mathrm{x}} \text { in inlet flue gas, } \mathrm{ppm}\right] /\left[10^{6}\right]} \\
& =\frac{\left(\mathrm{NH}_{3} \text { to absorber, scfm }\right)}{[\text { flue gas, } \mathrm{scfm}]\left[\left(\mathrm{NO}_{x}^{\mathrm{s1}}, \mathrm{ppm}\right) / 10^{6}\right]}
\end{aligned}
$$




\section{A.2.16 Regenerator Methane to Sulfur Molar Ratio $=$ M2}

This is a measure of stoichiometric ratio between methane and $\mathrm{SO}_{2}$ which is being removed from the flue gas and needs to be regenerated per unit time.

$$
\begin{aligned}
\mathrm{M} 2 & =\frac{\text { (methane flow, scfm) }}{\left(\mathrm{SO}_{2}\right. \text { removed in absorber, scfm) }} \\
& =\frac{\text { (methane flow, scfm) }}{\left[\mathrm { SO } _ { 2 } \text { removal eff, \%]/[100][flue gas flow, scfm] } \left[\left(\mathrm{SO}_{2} \text { inlet conc., ppm) } / 10^{6}\right]\right.\right.} \\
& =\frac{\text { (methane flow, scfm }]}{[\mathrm{E} 1 / 100][\text { flue gas flow, scfm }]\left[\mathrm{SO}_{2}{ }^{\mathrm{s}}, \mathrm{ppm}\right] /\left[10^{6}\right]}
\end{aligned}
$$

\section{A.2.17 Ammonia Slip $=\mathbf{M 3}$}

On-line analyzer has not yet been commercially purchased. Wet chemical method is being used.

\section{A.2.18 Sorbent Attrition, lb/cycle $=$ M4}

$$
\text { M4 }=\frac{\text { [lbs of sorbent makeup] }}{\text { [no. of sorbent cycles] }}
$$

\section{A.2.19 Sorbent Attrition, Percent Inventory/Cycle = M5}

$$
\begin{aligned}
\text { M5 } & =\frac{[100][\text { sorbent attrition, lb/cycle }]}{[\text { system sorbent inventory, lbs }]} \\
& =\frac{[100][\mathrm{M} 4, \mathrm{lb} / \text { cycle }]}{[\text { system sorbent inventory, lbs }]}
\end{aligned}
$$

\section{A.3 Sulfur Balance}

$$
=
$$

$\left(\mathrm{mol} / \mathrm{min} \mathrm{SO}_{2}\right.$ removed $)=(\mathrm{mol} / \mathrm{min} \mathrm{S}$ into regenerator $)-(\mathrm{mol} / \mathrm{min} \mathrm{S}$ out of regenerator $)$ 
Where

(1) $=\mathrm{lb}-\mathrm{mol} / \mathrm{min} \mathrm{SO}_{2}$ removed in absorber

$=0.01[\mathrm{E} 1]\left[\right.$ flue gas, scfm] $\left[\mathrm{SO}_{2}\right.$ conc, $\left.\mathrm{ppm}\right] /\left[\mathrm{molar}\right.$ vol @ STP, $\left.\mathrm{ft}^{3} / \mathrm{lb}-\mathrm{mol}\right] / 10^{6}$

$=0.01[\mathrm{E} 1][$ flue gas, $\mathrm{scfm}]\left[\mathrm{SO}_{2}^{\mathrm{s1}}, \mathrm{ppm}\right] /\left[379 \mathrm{ft}^{3} / \mathrm{lb}-\mathrm{mol}\right] /\left[10^{6} \mathrm{ppm}\right]$

(1) $=$ (alternative method)

$=\mathrm{lb}-\mathrm{mol} / \mathrm{min} \mathrm{SO}_{2}$ removed in regenerator

$=$ [regenerator off-gas, scfm] $\left[\mathrm{SO}_{2}\right.$ conc, ppm] $/\left[\mathrm{molar}\right.$ vol @ $\left.\mathrm{STP}, \mathrm{ft}^{3} \mathrm{hb}-\mathrm{mol}\right] / 10^{6}$

$=$ [regenerator off-gas, scfm $]\left[\mathrm{SO}_{2}^{\mathrm{s}}, \mathrm{ppm}\right] /\left[379 \mathrm{ft}^{3} / \mathrm{lb}-\mathrm{mol}\right] /\left[10^{6} \mathrm{ppm}\right]$

(2) $=\mathrm{lb}-\mathrm{mol} / \mathrm{min} \mathrm{S}$ into regenerator

$=0.01[\mathrm{wt} \% \mathrm{~S}$ in reg inlet sorbent][sorbent feed rate, $\mathrm{lb} / \mathrm{min}) /[\mathrm{MW} \mathrm{S}, \mathrm{lb} / \mathrm{b}-\mathrm{mol}]$

$=0.01[\mathrm{wt} \% \mathrm{~S}$ in reg inlet sorbent][sorbent feed rate, $\mathrm{lb} / \mathrm{min}) /[32.06 \mathrm{lb} / \mathrm{b}-\mathrm{mol}]$

(3) $=\mathrm{lb}-\mathrm{mol} / \mathrm{min} \mathrm{S}$ out of regenerator

$=0.01[\mathrm{wt} \% \mathrm{~S}$ in reg outlet sorbent][sorbent feed rate, $\mathrm{lb} / \mathrm{min}) /[\mathrm{MW} \mathrm{S}, \mathrm{lb} / \mathrm{lb}-\mathrm{mol}]$

$=0.01[\mathrm{wt} \% \mathrm{~S}$ in reg outlet sorbent][sorbent feed rate, $\mathrm{lb} / \mathrm{min}) /[32.06 \mathrm{lb} / \mathrm{lb}-\mathrm{mol}]$

A.4 $\mathrm{NO}_{x}$ Balance

(1) = (2) - (3)

$\left(\mathrm{mol} / \mathrm{min} \mathrm{NO}_{\mathrm{x}}\right.$ removed $)=\left(\mathrm{mol} / \mathrm{min} \mathrm{NH}_{3}\right.$ input to absorber $)-\left(\mathrm{mol} / \mathrm{min} \mathrm{NH}_{3} \mathrm{slip}\right)$

Where

(1) $=\mathrm{lb}-\mathrm{mol} / \mathrm{min} \mathrm{NO}_{\mathrm{x}}$ removed in absorber

$=0.01[\mathrm{E} 2]\left[\right.$ flue gas, scfm] $\left[\mathrm{NO}_{\mathrm{x}}\right.$ conc, ppm]/[molar vol @ STP, $\left.\mathrm{ft}^{3} / \mathrm{bb}-\mathrm{mol}\right] /\left[10^{6}\right]$

$=0.01[\mathrm{E} 2]\left[\right.$ flue gas, scfm] $\left[\mathrm{NO}_{\mathrm{x}}^{\mathrm{sl}}, \mathrm{ppm}\right] /\left[379 \mathrm{ft}^{3} / \mathrm{lb}-\mathrm{mol}\right] /\left[10^{6} \mathrm{ppm}\right]$

(2) $=\mathrm{lb}-\mathrm{mol} / \mathrm{min} \mathrm{NH}_{3}$ input to absorber

$=\left[\mathrm{NH}_{3}\right.$ inlet to absorber, $\left.\mathrm{lb} / \mathrm{min}\right] /[\mathrm{MW} \mathrm{NH}, \mathrm{lb} / \mathrm{lb}-\mathrm{mol}]$

$=\left[\mathrm{NH}_{3}\right.$ inlet to absorber, $\left.\mathrm{lb} / \mathrm{min}\right] /[17.03 \mathrm{lb} / \mathrm{lb}-\mathrm{mol}]$

(3) $=\mathrm{lb}-\mathrm{mol} / \mathrm{min} \mathrm{NH}_{3} \mathrm{slip}$

$=\left[\mathrm{NH}_{3}\right.$ in gas outlet,ppm][flue gas, scfm] $/\left[\right.$ molar vol @ $\left.\mathrm{STP}, \mathrm{ft}^{3} / \mathrm{lb}-\mathrm{mol}\right] /\left[10^{6}\right]$

$=\left[\mathrm{NH}_{3}\right.$ in gas outlet,ppm $][$ flue gas, $\mathrm{scfm}] /[379 \mathrm{ft} / \mathrm{lb}-\mathrm{mol}] /\left[10^{6} \mathrm{ppm}\right]$ 


\section{B.1 Vessel Drawings}

Vessel

Gravimetric feeder

Baghouse

Furnace

Incinerator

Absorber

Fluidized-bed heater

Fluidized-bed heater distributor

Regenerator

Fluidized-bed cooler

Flue gas cooler

Humidification chambers
Drawing Number

405-1-596

N74101640

MW-030-28

MW-030-40

D-1100

D-1133

MW-030-18

D-1125

D-1134

D-1175

D-1177

B.2 P\&ID

Flow Diagram

Coal storage silo

Combustor

Flue gas cooler

Absorber bypass

Cooling water system

Flue gas analysis(through Perma Pure)

Flue gas analysis(dry flue gas)

Flue gas analysis(ice bath)

Incinerator

Air heater

LCTS absorber/regenerator I

LCTS absorber/regenerator II

CuO LCTS Process Flow Diagram
Drawing Number
D-1144
D-1145

D-1146

D-1147

D-1148

D-1149

D-1150

D-1151

D-1152

D-1153

D-1154

D-1155

D-8656 


\title{
SORBENT ATTRITION TESTING IN THE LCTS
}

For the original $1 / 16 "$ sorbent, the sorbent was screened with the following:

\author{
U.S. Sieve Series No. 35 \\ 500 micron openings $\left(0.0197^{\prime \prime}\right)$ \\ Tyler equivalent 32 mesh
}

The procedure to investigate the attrition in the transport system is listed below. The figure is a schematic of the transport system on the LCTS.

1. Initially, an amount of sorbent was sieved on the screen.

2. Material remaining on the screen was weighed and then placed in the transport hopper inlet pipe. This roughly simulates sorbent flowing from the absorber.

3. The transport hopper level was set at $0.053 \mathrm{ft}^{3}$.

4. Two consecutive transports were conveyed to the 35 foot level and collected in a baghouse bag. The bag had been weighed prior to the test. Some very fine dust did go through the bag.

5. The sorbent was emptied from the bag and sieved. Fines were collected in a pre-weighed sample jar. Sorbent remaining was recycled back into the transport hopper inlet pipe.

6. The above steps were repeated until a total of 10 hopper loads were transported.

7. After the tenth load had been conveyed, a small amount of inventory remained in the transport hopper inlet pipe. This was conveyed in an eleventh transport cycle in order to capture all of the original inventory.

8. Total remaining inventory was screened. Material remaining on the screen was weighed. The total fines collected were weighed as was the final collection bag. Some material likely remained in the weave of the bag. After the fines screening, the sorbent was also sieved on a larger screen whose opening represented about $75 \%$ of the diameter of the pellet. For the original 1/16" sorbent, the coarser screen was:

$$
\begin{aligned}
& \text { U.S. Sieve Series No. } 16 \\
& 1190 \text { micron openings }(0.0469 ") \\
& \text { Tyler equivalent } 14 \text { mesh }
\end{aligned}
$$

The above steps were conducted during the testing of the original sorbent. Results are shown in the Table. It is known that transport pressure has a major impact on the attrition in the LCTS. When the pressure is decreased (but still capable of transporting the material), the attrition of the material decreases, as seen in the Table. 
With the 1/16" original sorbent, a test was conducted to determine the attrition produced across a hopper, including its inlet and outlet valves. The test was to confirm that the transport system and not the hoppers were the prime source of attrition. As seen in the attachment, the hopper test -- conducted in the regenerator outlet hopper -- was similar to the transport system test in the sense that ten cycles of material were sent through the system. Results with the $1 / 16$ " sorbent indicates that the attrition is less with the hopper system than with the transport system.

\begin{tabular}{||l|l|l|l|l|l||}
\hline \multicolumn{5}{|c|}{ ATTRITION TEST RESULTS - ORIGINAL 1/16" SORBEN } \\
\hline Test & $\begin{array}{l}\text { Regulator } \\
\text { Pressure } \\
\text { (psig) }\end{array}$ & $\begin{array}{l}\text { Transport } \\
\text { Pressure } \\
\text { (psig) }\end{array}$ & $\begin{array}{l}\text { Sorbent } \\
\text { Start } \\
\text { Weight } \\
\text { (g) }\end{array}$ & $\begin{array}{l}\text { Attrition } \\
\text { Fines } \\
\text { X< .0197 } \\
\text { (g) }\end{array}$ & $\begin{array}{l}\text { Attrition } \\
\text { Fines } \\
\text { (n) } \\
\text { (g) }\end{array}$ \\
\hline $\begin{array}{l}\text { Transport } \\
\text { 11/18/94 }\end{array}$ & 16.7 & 15 & 2240 & 52.2 & N/A \\
\hline $\begin{array}{l}\text { Reg } \\
\text { Outiet } \\
\text { Hopper } \\
11 / 22 / 94\end{array}$ & N/A & N/A & 4800 & 1.9 & N/A \\
\hline $\begin{array}{l}\text { Transport } \\
12 / 13 / 94\end{array}$ & 16.7 & 15 & 2250 & 53.9 & N/A \\
\hline $\begin{array}{l}\text { Transport } \\
12 / 14 / 94\end{array}$ & 9 & 8 & 2250 & 10.3 & 12.9 \\
\hline
\end{tabular}


2.76621203475
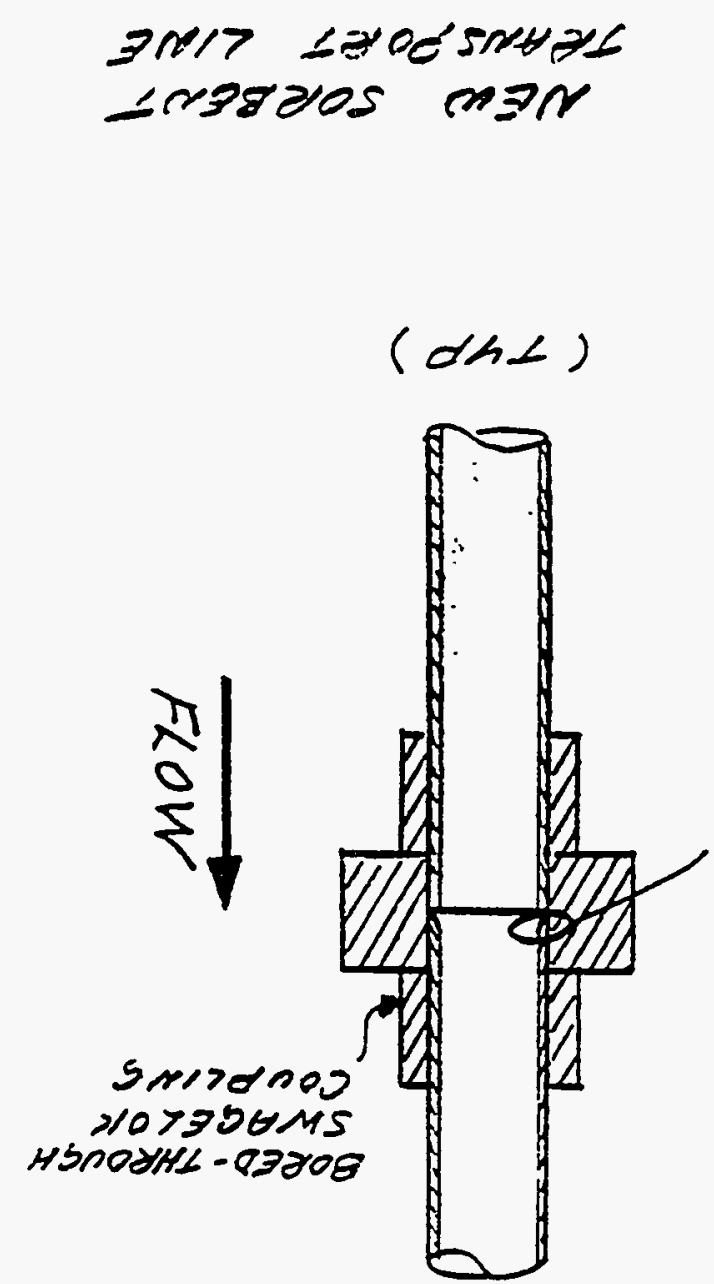

09
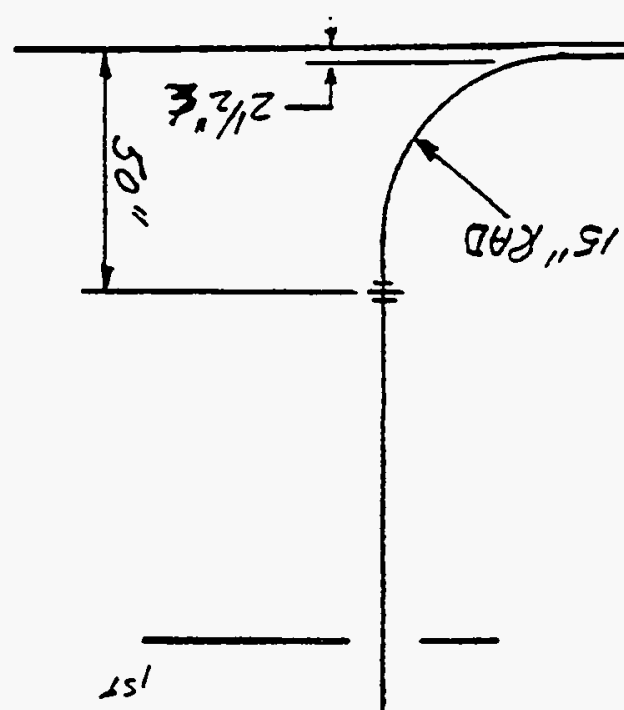

3804
3804

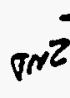

$38 n 1$
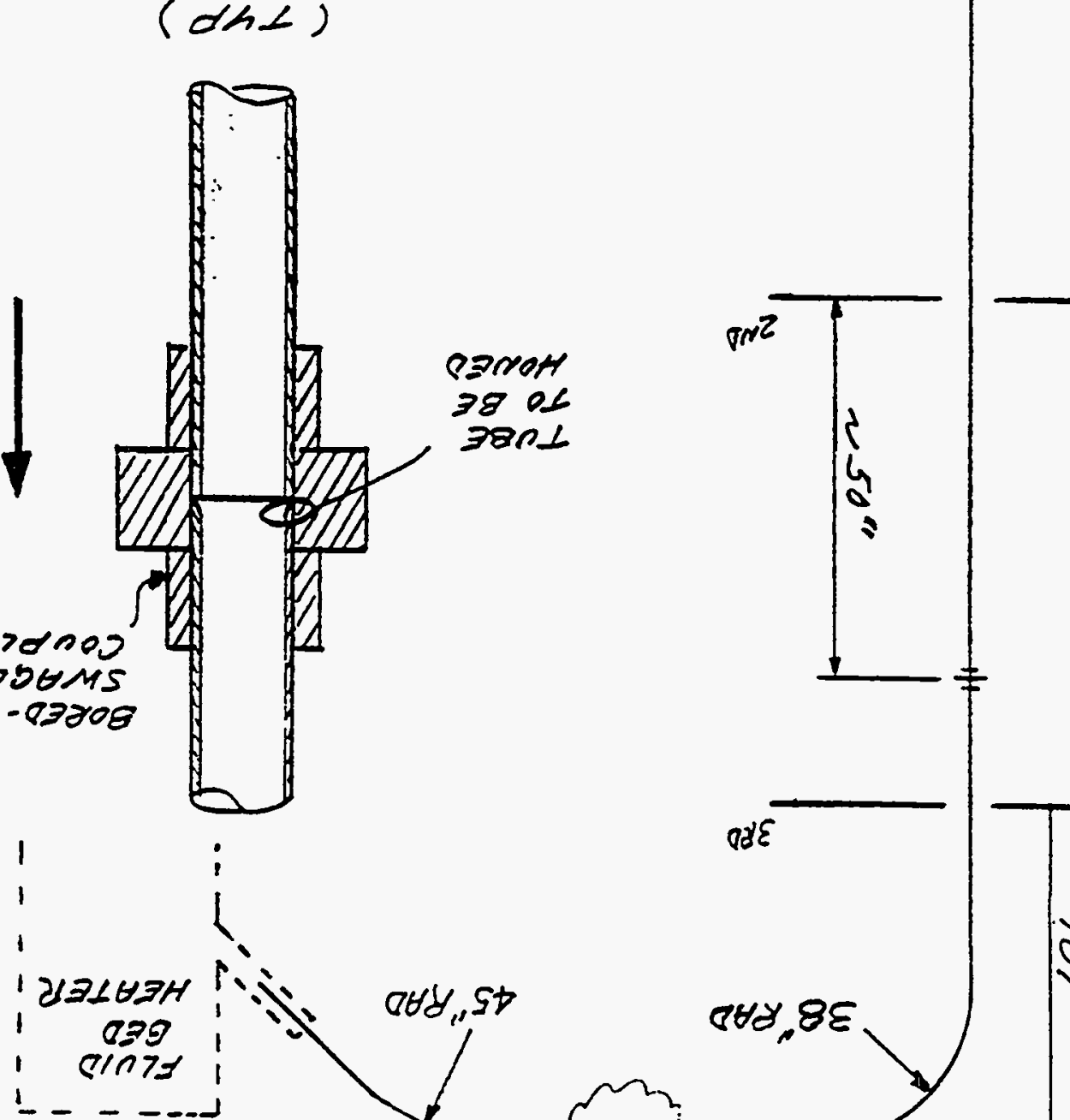

i<smiles>C#CC[AsH2]</smiles>

จd

848, $8 \varepsilon$
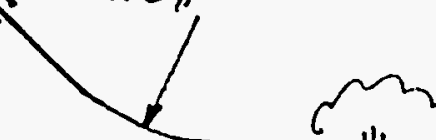
Engineering Instruction No. 2

CALCULATION

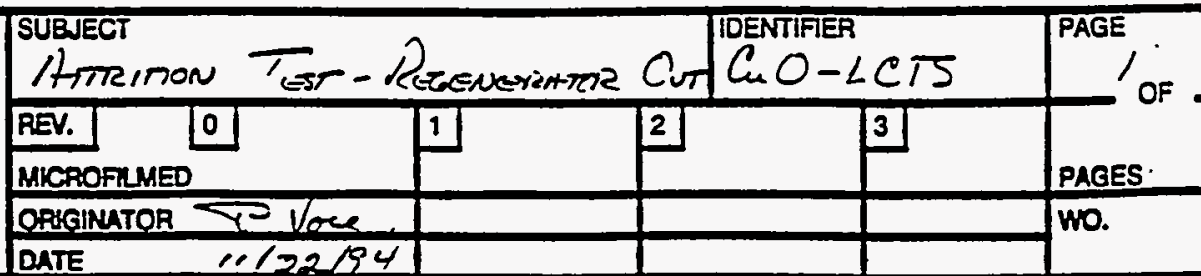

Broblem/PuRPose:

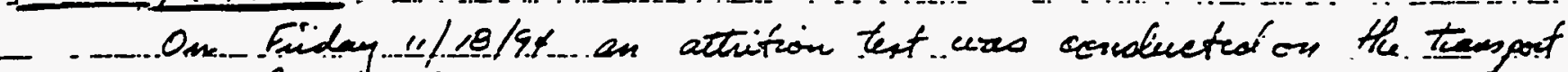

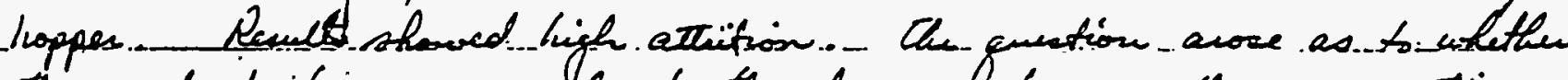

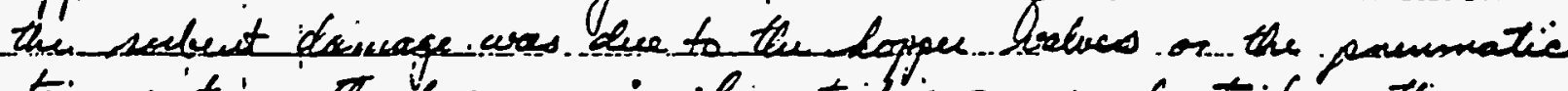

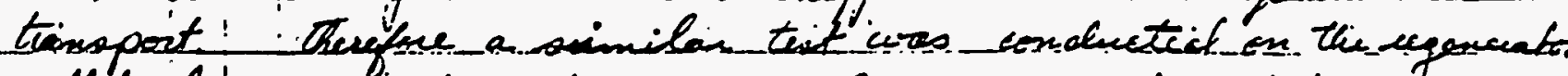

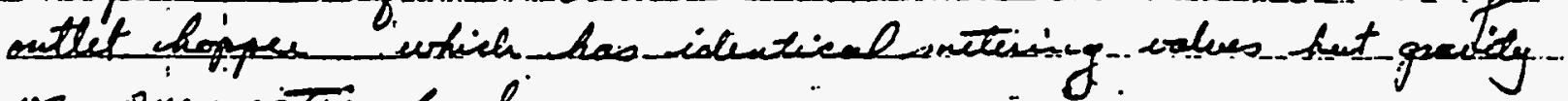
us par fendi.

Procaroure:

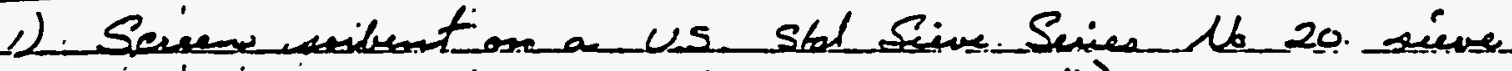

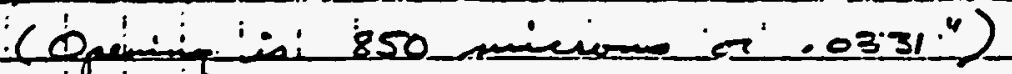

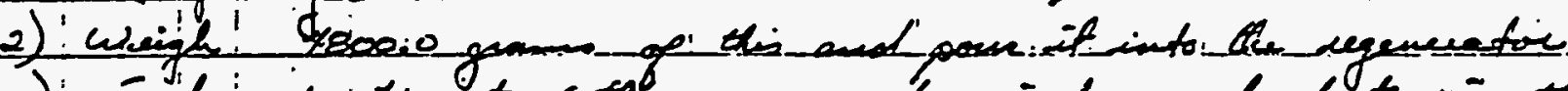

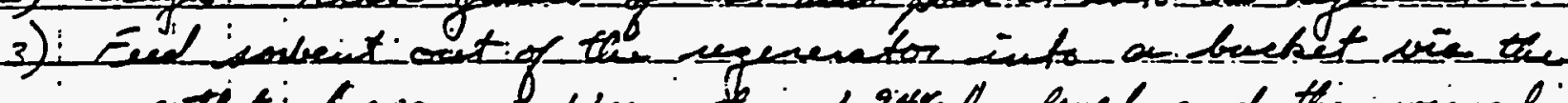

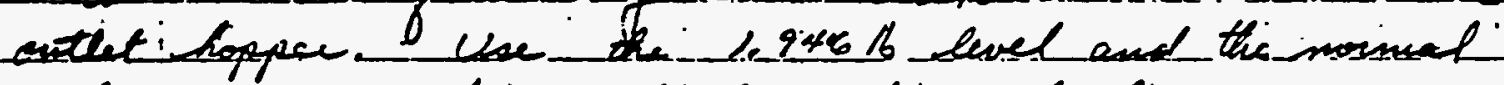

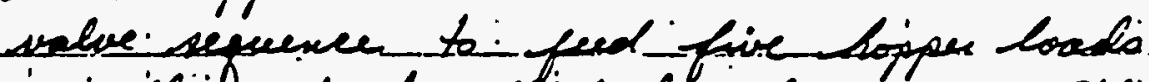

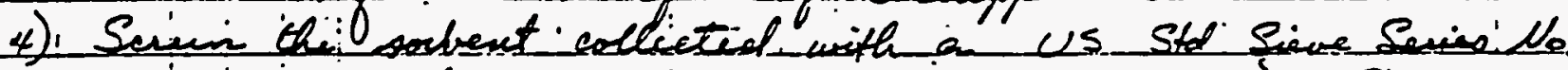

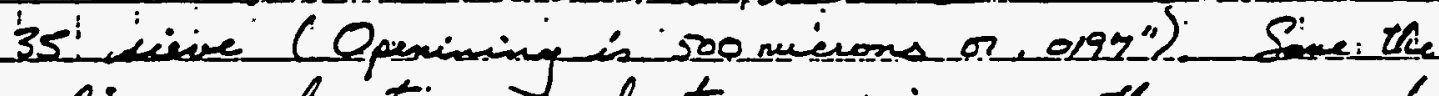

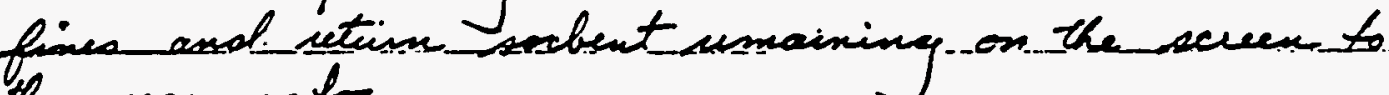
the segencuntor.

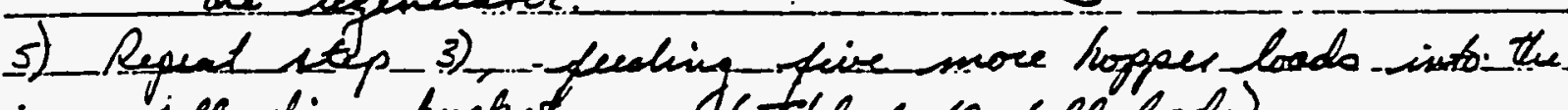

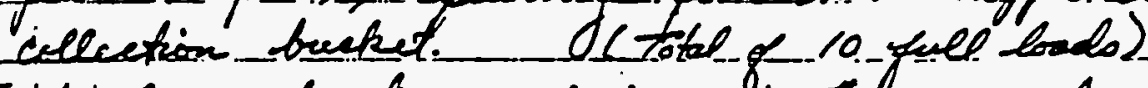

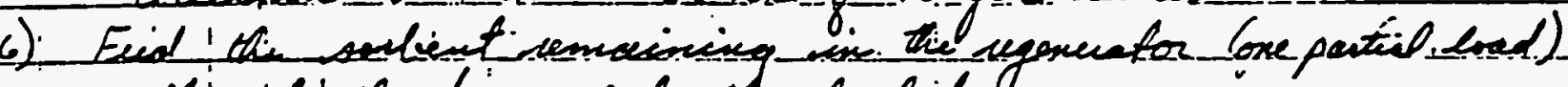
thingls! the hopper into the bueketo

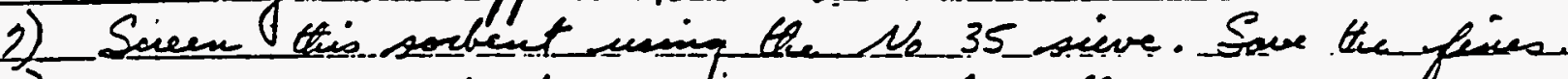

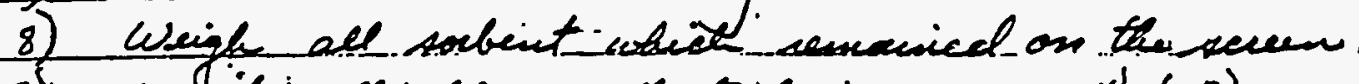

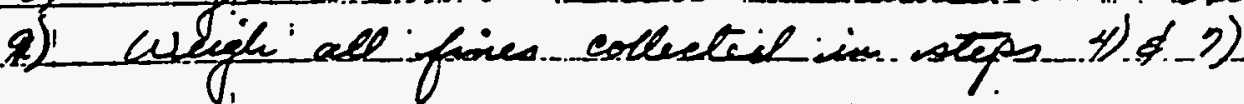

'Deta is bhow ion next' page

Fines diluiered to Iin Hepen $11 / 22 / 94$

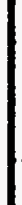
$\because$ 
Engineering Instruction No. 2

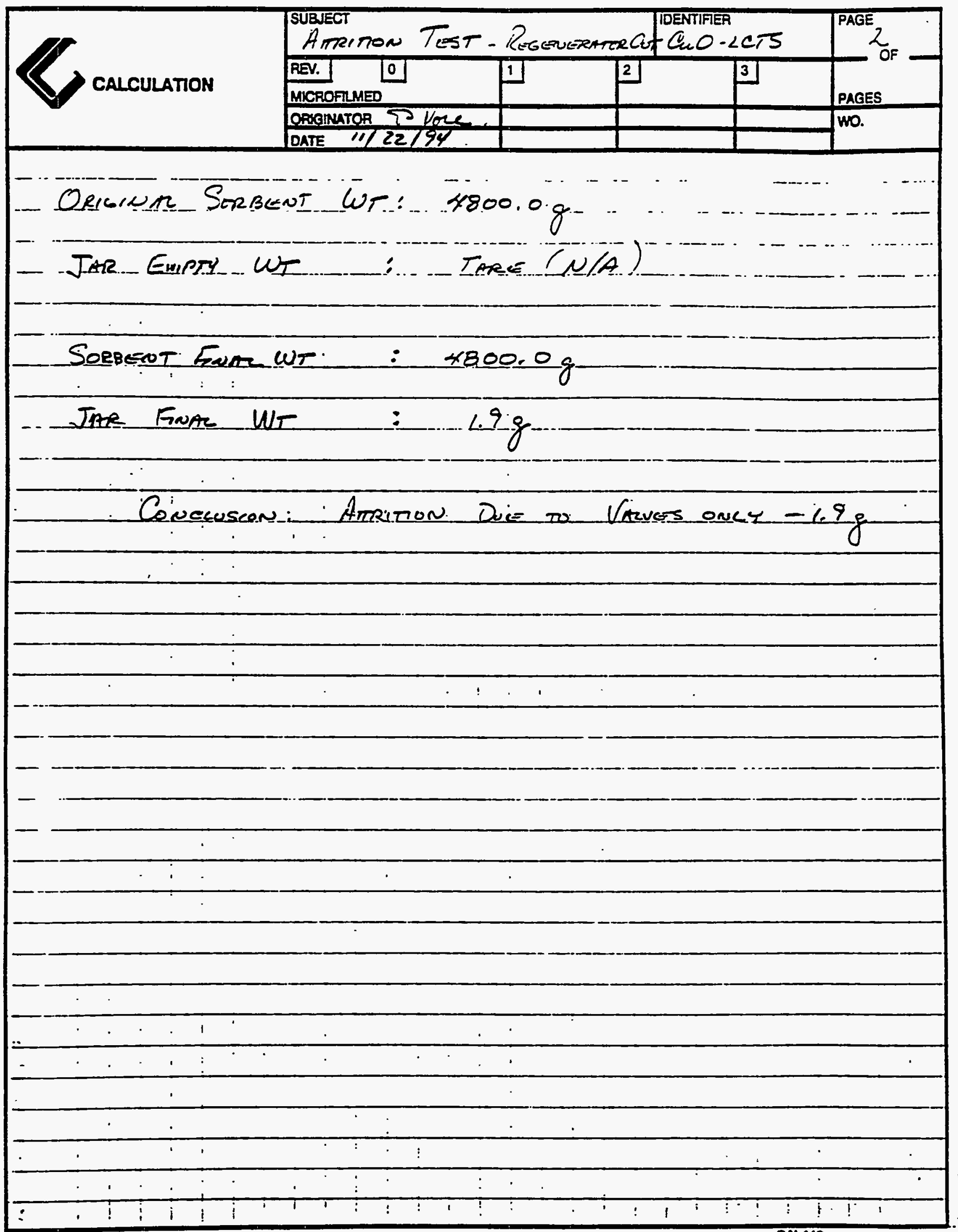

